\title{
Globalization, Government Popularity, and the Great Skill Divide
}

\author{
Cevat G. Aksoy, Sergei Guriev, Daniel S. Treisman ${ }^{1}$
}

May 2020

\begin{abstract}
How does international trade affect the popularity of governments and leaders? The recent backlash against globalization renders this question extremely topical. Yet, most previous work has looked for political effects of aggregate trade flows without decomposing into particular types of products. We provide the first large-scale, global evidence that trade shocks affect political approval and show that what matters is the match between workers' skills and the characteristics of goods traded. Using a unique data set including 118 countries, we show that growth in high skill intensive exports increases approval of incumbents among skilled individuals. Growth in high skill intensive imports has the opposite effect. High skill intensive trade has no discernible effect on the unskilled. To identify exogenous variation, we exploit the time-varying effects of air and sea distances on bilateral trade flows. Our findings help explain responses to trade of economic elites in developing and middle income countries.
\end{abstract}

JEL Codes: D72; F14; G02; P16

Keywords: International trade; political approval; skill intensity of trade.

${ }^{1}$ Aksoy is a Principal Economist at the European Bank for Reconstruction and Development (EBRD), part-time Assistant Professor of Economics at King's College London and Research Associate at IZA Institute of Labour Economics. Guriev is the Chief Economist at the EBRD, a Professor of Economics at Sciences Po, and Research Fellow at the Centre for Economic Policy Research. Treisman is a Professor of Political Science at the University of California, Los Angeles and Research Associate at the National Bureau of Economic Research. We would like to thank Dany Bahar, Pranab Bardhan, Paola Conconi, Georgy Egorov, Thiemo Fetzer, Jack Hou, David Laitin, Anna Maria Mayda, William Olney, Kevin O'Rourke, Hillel Rapoport, Victor Shih, Ekaterina Zhuravskaya and participants at the Beijing Forum, DEGIT, European University Institute, Royal Economic Society, CEPR-EBRD-EoT, CESifo Venice Summer Institute, Fudan University, the World Bank and IBS conferences for their helpful comments. Views presented are those of the authors and not necessarily those of the EBRD. All interpretations, errors, and omissions are our own. 


\section{Introduction}

The politics of trade has recently dominated headlines. A US presidential election turned in large part on one candidate's promise to get tough against imports from China and Mexico - a promise he later fulfilled by withdrawing from and renegotiating trade treaties. Across Eastern Europe, populist leaders have campaigned against further EU integration, and in the UK a majority voted to leave the union. Although anxiety about immigration and weakened sovereignty are common themes in the discontent, anger at the perceived loss of jobs to international competition is also highly salient.

Some argue that attitudes toward globalization have emerged as a new dimension of political alignment, alongside the traditional left-right redistribution axis. "The new divide," according to the Economist magazine (2016) "is not between left and right but between open and closed." "2 If that is true, current political turbulence may foreshadow lasting changes.

Yet, although some scholars have explored implications of classic trade theories for preferences on trade policy (Scheve and Slaughter 2001, O'Rourke and Sinnott 2001, Mayda and Rodrik 2005), until very recently there has been little systematic empirical analysis of the links between global trade and mass politics. A few papers have examined whether import competition in the US has affected voting patterns in national elections (Margalit 2011, Autor et al. 2016, Jensen et al. 2017, Che et al. 2016), while some others have studied voting in Europe (Dippel, Gold, and Heblich 2015, Colantone and Stanig 2016, 2017). The general finding has been that sharp import shocks increase partisan polarization or voting for populist parties.

We contribute to this literature by examining whether international trade affects not just voting at periodic elections but also the approval ratings of governments and political leaders in between. And we disaggregate to investigate effects of different types of trade on citizens with different skill levels. Using annual data from the

\footnotetext{
${ }^{2}$ See also De Vries (2017) on the cosmopolitan-parochial divide in recent Dutch elections.
} 
Gallup World Poll for 2005-15, we provide the first large-scale, systematic evidence on this issue.

The period in question is a particularly rich one to explore the political effects of trade. Several major global influences were raising its political salience. First, the massive increase in Chinese exports after its 2001 entrance into the WTO was disrupting previous trade patterns, with significant effects on particular communities (see for example, Autor et al. 2013 for the United States, Mion and Zhu 2013 for Belgium, Colantone et al. 2015 for the UK, Utar 2018 for Denmark and others). Second, the severe financial crisis and worldwide recession of 200910 - which, at least temporarily, halted momentum toward globalization - were also bound to influence politics (see for example, Algan et al. 2017). Many scholars saw the rise of populism as a direct result of these economic phenomena.

We suggest here that the political effects of these changing trade dynamics may be more complex. Different groups in different countries were affected in different ways. Drawing on the factor endowment theory, we argue that attitudes toward globalization will depend on both individuals' skill levels and the skill-intensity of their country's exports and imports. ${ }^{3}$ To address the endogeneity of trade patterns, we use instruments based on the time-varying bilateral air and sea transport costs, originally proposed by Feyrer (2009) and later used by other trade scholars. The panel structure of the data also allows us to control for country and year fixed effects.

Our results reveal a causal impact of changing trade flows on approval of political leaders. We find that the effects of trade shocks depend on the interaction between individuals' characteristics and their country's trade structure. Highly skilled workers respond to trade in high skill intensive goods and services differently than do unskilled workers. This is true even though skilled and unskilled workers do not

\footnotetext{
3 Throughout the paper, we use the term 'skilled' or 'highly skilled' to refer to individuals with at least tertiary education. Individuals with less than tertiary education are referred to as 'unskilled'. We check robustness to an alternative definition in Section 5.3
} 
respond differently to total trade. Specifically, highly skilled individuals approve of their leader and government more when exports of high skill intensive goods and services increase and when imports of high skill intensive items decrease. The magnitudes are substantial: a 10 percent increase in skill-intensive exports results in a 1.17 percentage point rise in the leader's approval among skilled individuals, while a 10 percent increase in skill-intensive imports prompts a 1.65 percentage point drop in the leader's approval among the skilled. Given the closeness of certain recent elections, such changes could decide electoral outcomes.

Our analysis offers the broadest cross-national evidence to date on the relationship between trade and political attitudes. Whereas previous papers have mostly looked at individual countries or smaller samples, our data cover 118 countries, both developed and developing, over an 11-year period. This allows greater confidence in the generality of the findings. It also makes it possible to investigate heterogeneity of responses to trade shocks based on various individual and countrylevel characteristics. In particular, we are able to connect the skill characteristics of individuals to the changing skill content of their country's exports and imports. Furthermore, by incorporating country and year fixed effects and country-specific linear time trends and by instrumenting for changes in skill-intensive trade, we address many potential concerns related to endogeneity and reverse causality.

As our instrumentation strategy works only for high skill intensive trade and not for low skill intensive trade, we cannot test the causal impact of the rise of lowskilled trade on political approval. Our OLS estimations do not produce significant correlations between changes in low-skilled trade and political attitudes.

Our results cast light on a side of the politics of trade that has attracted less attention than the impact of imports on workers in advanced economies. In less developed countries, it is often the relatively highly skilled who are hit hardest by greater trade openness. Whereas the shock from cheap imports may fuel populist campaigns in the West, competition from skill-intensive manufacturing and services may drive 
educated elites to protectionism in the developing world. The evidence suggests that something like this has, indeed, occurred, although it may be offset at times by the benefits skilled workers in developing countries obtain from the offshoring of jobs by advanced economies.

The paper proceeds as follows. Section 2 discusses related literature and motivates our hypotheses. Section 3 describes the data. Section 4 outlines our empirical approach and instrumentation strategy. Section 5 presents the results. Section 6 concludes.

\section{Trade and Politics}

Classic theories of trade suggest that how international openness affects different groups depends on their factor endowments and comparative advantage. The Heckscher-Ohlin and Stolper-Samuelson theorems show that assuming perfect competition, constant returns to scale, and costless factor mobility across sectors, openness benefits owners of each country's abundant factors and hurts owners of scarce factors. In particular, free trade should raise the wages of skilled workers in developed countries, where such workers are plentiful, and the wages of unskilled workers in poor countries, where skilled labor is scarce. The main rival theory, the Ricardo-Viner specific factors model, assumes certain factors are immobile between sectors. In this case, all workers in a given industry-whether skilled or unskilled-have similar interests. They do better under openness if their country has a comparative advantage in their industry, and worse if it does not. Recently, the "new new" trade theory of Melitz (2003) and others has argued that, within each industry, larger, more productive firms benefit from trade openness at the expense of smaller and less productive ones. The implication is that trade should benefit skilled workers, who are disproportionately employed by more productive, exportoriented companies. 
Economic interests imply policy preferences. In a Heckscher-Ohlin world, skilled workers should favor free trade if they live in skill-rich countries, but protection if they live in skill-poor ones. ${ }^{4}$ The opposite holds for unskilled workers. In a world of specific factors, workers in internationally competitive industries should favor open borders, while those in uncompetitive ones should demand high tariffs. ${ }^{5}$ In a "new new" trade theory world, the effects of trade on factor classes and industries are either amplified or offset by the skill-biased impact of trade within each industry (Burstein and Vogel 2017). Thus, even in skill-poor countries, high skilled workers might still benefit from trade on balance.

Empirical studies testing these hypotheses against survey data have found some support for the Heckscher-Ohlin predictions, but less for Ricardo-Viner. In the US, highly skilled workers - as proxied by education - are more likely to favor openness, consistent with the factor endowment story (Scheve and Slaughter 2001). However, other interpretations are also possible. Education could affect policy preferences by inculcating greater tolerance toward foreigners, encouraging risk acceptance, and increasing understanding of the benefits of commerce (Hainmueller and Hiscox 2006, Rho and Tomz 2017). Studies that use other measures of skills such as the occupational wage have found no effect on trade attitudes (Mansfield and Mutz 2009, p.429).

Two papers use cross-national surveys to investigate the interaction between skill levels of the individual and the country more precisely. O'Rourke and Sinnott (2001) and Rodrik and Mayda (2005) both found that, while highly skilled individuals supported free trade in richer countries (where high skills are more abundant), they opposed it in poorer countries. This evidence, consistent with Heckscher-Ohlin, is somewhat surprising given that the assumptions of the model are clearly not met in reality. Besides the lack of perfect competition in many

\footnotetext{
${ }^{4}$ For a classic investigation of the role of such factors in history, see Rogowski (1989).

${ }^{5}$ See Bernard et al. (2007) for a discussion of traditional and new trade theories.
} 
countries and the importance of economies of scale, observed patterns of trade do not fit the expectation Heckscher-Ohlin theory generates of predominantly NorthSouth flows. As Baldwin (2008, p.8) notes, empirical tests have "revealed little support for the HO [Heckscher-Ohlin] proposition that countries export their relatively abundant factors (embodied in goods) and import their relatively scarce productive factors."

This research provides evidence on the link between skill levels and attitudes towards trade. But it does not examine whether such attitudes influence political preferences and behavior. It is natural to assume that the material losers from increased openness will not only favor protection but also vote and protest against incumbents who fail to protect their markets. A small but growing literature looks for such political effects.

Four recent papers evaluate the impact of international trade on voting in the US. Margalit (2011) shows that job losses from import competition depressed the vote share of the incumbent president in 2004 and 2008. Jensen et al. (2017) also find that trade-related losses in manufacturing cost incumbents votes. Conversely, they show that rising employment in high-skill export industries led to higher incumbent support. Autor et al. (2016) examine the polarization of U.S. politics and find that congressional districts exposed to greater increases in import penetration (due to the "China import shock" following China's accession to the World Trade Organization) disproportionately removed moderate politicians from office in the 2000s. Che et al. (2016), examining voting across US counties and exploiting change in US trade policy, found that increased exposure to Chinese competition increased voting for Democrats in congressional elections.

Our results are also related to a developing literature that explores the differentiated impact of particular groups and even individual firms on the politics of trade (e.g., Bombardini 2008, Kim 2017). While many previous studies focused on the interests of whole industries or classes of factor owners, more recent work, building on the 
"new new" trade theory, has disaggregated industries into different types of firms (Osgood et al. 2017). In parallel, scholars have sought to decompose labor into narrower sub-categories. Some analyses of the US, for instance, have indeed found political effects of trade differentiated by the skill levels of workers (Jensen et al. 2017).

Fewer papers have looked for political consequences of trade in a cross-national context. One exception is Colantone and Stanig (2017), who examine how globalization has affected electoral outcomes in 15 West European countries in 1988-2007. They find that greater exposure to the shock of Chinese import competition predicts a shift to the right in voting, including greater support for nationalist parties and the radical right. Margalit (2017), using data from the ISSP survey, finds that those in advanced economies who feel they have suffered from international trade tend to support parties that favor economic protection but sociocultural conservatism.

We build on both strands of this literature. Following the Heckscher-Ohlin-inspired studies of policy preferences, we hypothesize that attitudes will depend on the interaction between an individual's skill level and the skill-intensity of the country's imports and exports. We disaggregate individuals and trade flows by skills. As in the recent papers on political consequences, we reach beyond selfreported attitudes towards trade, which may be superficial for many citizens and unlinked to political behavior, to study support for incumbent officials, which has clearer consequences. At the same time, rather than assuming a particular pattern of trade flows based on countries' factor endowments - a pattern known to be at best only partly accurate - we use a direct measure of trade disaggregated on the basis of skill-intensity of the products. Our main hypothesis is that skilled workers are more likely to support the incumbent national leadership if high skill-intensive imports are falling and skill-intensive exports are growing. 


\section{Data}

The data used in this paper come from the Gallup World Polls, the United Nations International Trade Statistics Database (COMTRADE), CEPII, the World Bank's World Development Indicators (WDI), the Integrated Network for Societal Conflict Research Database, Polity IV, and Freedom House. The level of analysis is the individual level. We describe the data below.

\subsection{Individual Level Data from Gallup World Polls}

Our primary data on political approval come from the 2005-2015 Gallup World Polls (GWP). These nationally representative surveys are fielded every year in over 120 countries and interview approximately 1,000 individuals in each country on a wide range of topics. Our main sample includes nearly 450,000 respondents from 118 countries. ${ }^{6}$ We restrict attention to those aged 25 to 64 to focus on economically active individuals who have most likely completed their education. ${ }^{7}$ All responses regarding education are coded into the following categories for global comparison: Elementary (up to 8 years of basic education); Secondary (9 to 15 years of education); and Tertiary (completed 4 years of education beyond "high school" and/or received a four-year college degree).

The key outcome variables in this paper come from questions asked to all Gallup respondents about the job performance of the incumbent leader and confidence in the national government: (i) "Do you approve or disapprove of the job performance of the leadership of this country?"; (ii) "In (this country), do you have confidence in each of the following, or not: ... How about national government?". The GWP also provides detailed information on respondents' demographic characteristics (age, gender, educational attainment, marital status, religion, and urban/rural residence), labor market outcomes, and income. Controlling for employment status and income allows us to measure the impact of trade on political approval beyond

\footnotetext{
${ }^{6}$ We drop observations for Nagorno-Karabakh, Northern Cyprus, Somaliland, and Puerto Rico.

${ }^{7}$ We tried lowering the minimum age to 18 years and found no qualitative change in the results.
} 
trade's direct effect on households' material well-being. We also examine responses to four parallel questions, as placebo outcomes, about whether the respondents have confidence in: (iii) the military; (iv) honesty of elections; (v) the judicial system; and (vi) media (freedom). ${ }^{8}$

\subsection{International Trade Data}

We obtained product-level export and import data on goods and services from the UN COMTRADE database for the years 2005-2015. More specifically, we use the 3-digit Standard International Trade Classification (SITC - revision 3) to categorize manufactured goods by their skill intensity (that is, labor-intensive, low-skill intensive, medium-skill intensive, and high-skill intensive). ${ }^{9}$ The data on exports and imports of services employ the EBOPS classification. We use correspondence tables provided by the Manual on Statistics of International Trade in Services (2002) to classify trade in services by their skill intensity (see Appendix Table 18 for details). These skill-based classifications reflect common perceptions regarding different skill-intensities in the production line and give a broad indication of sectoral differences in terms of the potential for productivity growth (Mayer et al., 2003). In both datasets, values are reported in nominal U.S. dollars. We adjust these values to 2011 dollars using the consumer price index. Using these data, we calculate the variable Total Volume of High Skill Intensive Exports (Imports). Some examples of high skill intensive goods and services include electronics, parts and components for electronics, medical and chemical products, optical goods, and auditing, financial, and legal services. Goods such as cutlery, fencing grills, metal containers for storage or transport, and office supplies are classified as low-skill

\footnotetext{
${ }^{8}$ These questions are part of a Gallup 'national institutions index'. Note that if a respondent asks for clarification or interpretation of the question, Gallup surveyors are trained to answer "However you interpret the question," or "It is whatever the question means to you." If a respondent asks whether there is a more neutral response option than "yes" or "no," surveyors are trained to ask whether "there is one that you lean more towards."

${ }^{9}$ In what follows, we focus on high-skill intensive goods and services and describe other goods and services as "low-skilled" (thus grouping together labor-intensive, low-skill intensive, and mediumskill intensive ones). Detailed information on product grouping of goods and services can be found at: http://unctadstat.unctad.org/EN/Classifications.html.
} 
intensive products. We provide detailed information about the skill classification in the appendix. ${ }^{10}$

To construct our instruments, we mainly use two datasets. The first is the special license version of the UN COMTRADE data, which provides bilateral trade flows between countries at the product and service level. ${ }^{11}$ The raw dataset includes more than 250 million year-country-pair (exporter-importer) observations. We first classify each trade flow based on its skill intensity. We then calculate the sum of trade values by year-country-trade-partner for each country. The second dataset comes from the CEPII. More specifically, we use the Historical Bilateral Trade and Gravity Dataset (TRADHIST) that was compiled by Fouquin and Hugot (2016) to obtain information on bilateral trade characteristics, including geographical distance, common borders, and colonial and linguistic links. There are three main measures of bilateral distance: a city population-weighted mean of the great-circle distance between each pair of countries; the great-circle distance between the two largest cities of each country pair; and the shortest maritime distance between two countries (for landlocked countries, Fouquin and Hugot (2016) choose the closest foreign port and report the distance accordingly). ${ }^{12}$

\subsection{Time-Varying Country Characteristics}

We also control for several time-varying country characteristics in our main specification, including the country's political regime (from the Polity IV dataset)

\footnotetext{
${ }^{10}$ Of course, some low-skilled as well as high-skilled individuals work in sectors such as electronics, so these classifications rank sectors by the average level of skill-intensity.

${ }^{11}$ An important caveat is that our data do no fully account for the composition of cross-border value chains. When China imports skill-intensive goods and services needed to produce an iPhone and then assembles and exports an iPhone, this is recorded in our data as high skill imports into China and high skill exports from China. On the other hand, it is likely that these are the gross trade flows that are observed by voters and therefore affect political attitudes. We explore the role of outsourcing in Section 5.3.

${ }^{12}$ Fouquin and Hugot (2016) obtained information on all maritime distances from vesseltracker.com (2014). They first identified the largest port in each country (two ports if the country was bordered by two different seas or oceans) and chose the shortest maritime distance between any of the ports of both countries.
} 
and population, Freedom House's Press Freedom Index, GDP per capita, the import to GDP ratio, and the export to GDP ratio obtained from the World Bank's World Development Indicators database. ${ }^{13}$ As a robustness check, we also control for leaders' tenure (i.e., the number of consecutive years served in the top office). The data on this variable come from the Database of Political Institutions, with our updates (Cruz, Keefer, and Scartascini 2016).

\subsection{Descriptive Statistics}

Table 1 presents descriptive statistics for the outcome variables, country characteristics, and individual demographic characteristics. Figure 1 shows the global trends in approval over our sample period, averaged across all countries for which data were available in seven or more years. Several patterns are notable. First, averaging across all country-years, almost 50 percent of respondents say they approve of the performance of the leader or have confidence in the national government. Worldwide, approval rises during the global boom years of 2005-7; falls during the global financial crisis of 2009-10; regains some ground; but then falls again in the sluggish economic recovery.

These figures mask substantial heterogeneity within and across countries. For example, the lowest approval ratings for leaders were recorded in particular years in Bosnia and Herzegovina (17 per cent), Angola (21 per cent), Romania (22 per cent), Ukraine (23 per cent), and Peru (23 per cent). Bhutan (95 per cent), Singapore (94 per cent), Vietnam (92 per cent), Azerbaijan (88 per cent), and Kazakhstan (87 per cent) had the highest leader approval. Confidence in government was lowest in Ukraine, Romania, Peru, Moldova and Bosnia and Herzegovina, ranging from 19 to 23 per cent. By contrast, in Namibia, Azerbaijan, Sri Lanka, Ethiopia, Singapore,

\footnotetext{
${ }^{13}$ Of course, exports and imports as a share of GDP are affected by skill intensive exports and imports, and so can be considered post-treatment. We control for these in certain models only to demonstrate robustness.
} 
Vietnam, and Bhutan, more than 80 per cent of respondents reported confidence in their government.

These figures suggest that: (i) the two outcome variables (approval of leaders and confidence in national government) are highly correlated; and (ii) respondents in democratic countries tend to report lower levels of government approval. ${ }^{14}$ On average, 47 per cent of skilled individuals report confidence in government and 49 per cent of skilled individuals approve the job performance of their leader.

The patterns of high skill intensive exports and imports vary substantially. Averaged across available years, Luxembourg (52 per cent), Ireland (46 per cent), and Singapore (45 per cent) had the highest shares of skill intensive exports (as a percentage of total exports of goods and services), and China, the United States, and Germany had the highest total volumes of these. By contrast, the shares were lowest in Venezuela (1.1 per cent), Azerbaijan ( 0.8 per cent) and Nigeria ( 0.6 per cent) and the volumes were lowest in Burundi, Rwanda, and Zimbabwe. Countries' shares of high-skill-intensive imports (as a percentage of total imports of goods and services) ranged from highs of 50 to 72 per cent in Rwanda, Lebanon, Malawi, Nepal and Burundi to lows of 5 to 10 per cent in Azerbaijan, Trinidad and Tobago, Qatar, Oman, and Bahrain. Turning to volumes, the United States, China and Germany imported the most high skill intensive goods and services, while Burundi, Niger, and Togo imported the least.

Looking at placebo outcomes, we see that people tended to have confidence in the armed forces (72 per cent for the military), while only about half of respondents worldwide had confidence in the honesty of elections, the judicial system, and the media. Moreover, differences in these are very large, with about 20-50 percentage point gaps between democracies and non-democracies.

14 This is consistent with Guriev and Treisman (2017). 


\section{Estimation Methodology}

\subsection{Empirical Strategy}

To assess the effect of international trade on approval of the leader and confidence in the national government, we start by estimating ordinary least squares models. We use the following specification:

$\mathrm{Y}_{\mathrm{ict}}=\beta_{0}+\beta_{1} \mathrm{X}_{\mathrm{ict}}+\beta_{2}$ Skilled $_{\mathrm{ict}} *(\text { Log High Skill Intensive Exports })_{\mathrm{ct}}$

$+\beta_{3}$ Skilled $_{\text {ict }} *(\text { Log High Skill Intensive Imports })_{\mathrm{ct}}+\beta_{4}$ Skilled $_{\mathrm{ict}}+$

$+\beta_{5} *(\log \text { High Skill Intensive Exports })_{\mathrm{ct}}+$

$+\beta_{6} *(\log \text { High Skill Intensive Imports })_{\mathrm{ct}}+$

$+\beta_{7} \mathrm{Z}_{\mathrm{ct}}+\beta_{8} \mathrm{C}_{\mathrm{c}}+\beta_{9} \mathrm{~T}_{\mathrm{t}}+\beta_{10} \mathrm{C}_{\mathrm{c}}{ }_{\mathrm{t}}+\varepsilon_{\mathrm{ict}}$

where $Y_{i c t}$ is a dummy variable indicating that the respondent approves of "the job performance of the leadership of their country" or the respondent has "confidence in national government" depending on the model, for individual $i$ in country $c$ at time $t$. We estimate linear probability models for ease of interpretation.

To adjust for the effect of demographic and labor market structure on the outcome variables, we directly control for time-varying, observable individual characteristics. More specifically, $X_{i c t}$ is a vector of demographic variables that (depending on the model) include: a male dummy; age and age squared; dummy variables for marital status (married/civil partnership and divorced/separated); a dummy variable for the presence of children in the household (any child under 15); and a dummy variable for living in an urban area. To account for pro-cyclical variation in labor market outcomes, we control for the log of household income. ${ }^{15}$ Note that we do not control for individual-level unemployment in our baseline

\footnotetext{
15 Gallup converts local income to International Dollars using the World Bank's individual consumption PPP conversion factor. This makes income estimates comparable across all countries.
} 
specification since this information is only available in the GWP from 2009. Below we show that our results are robust to this choice.

Skilled is an indicator variable equal to one for individuals with at least tertiary education. ${ }^{16}$ The excluded category for education in all models consists of individuals who report less than tertiary education, which we label unskilled. Log High Skill Intensive Exports (Imports) is the natural log of the total volume of high skill intensive exports (imports) of good and services. The main coefficients of interest are the interaction terms $\beta_{2}$ and $\beta_{3}$, which capture the impact of growth in the total volume of high skill intensive exports and imports on the approval levels of high-skilled (relative to unskilled) individuals. The coefficients $\beta_{5}$ and $\beta_{6}$ measure the impact of growth in the total volume of high skill intensive exports and imports on approval levels of unskilled individuals. $Z_{c t}$ is a vector of other potentially relevant country-time varying characteristics that could be correlated with political approval. These include political regime characteristics of a country (Polity IV), the Freedom House Press Freedom Index, the log of GDP per capita, and the log of country population. To account for other unobservable characteristics, we include a full set of country $\left(C_{c}\right)$ and year $\left(T_{t}\right)$ dummies. The country dummies control for all time-invariant variation in the outcome variable caused by factors that vary cross-nationally. Year dummies capture the impact of global shocks that affect all countries simultaneously. We also include multiple language and interview type dummies throughout, though we do not report them in equation 1. In addition, we control for country-specific linear time trends, $C_{c} * t$, thus removing distinctive trends in opinion in various countries that might otherwise bias our estimates if they accidentally coincided with trade-related changes. In the fully saturated models, the estimates are identified by exploiting within-country variation that has been stripped of any influence of constant and linearly changing country

\footnotetext{
16 We also estimate models where we include both tertiary and secondary education dummies and their interaction terms with Log High Skill Intensive Exports (Imports) in Table 20.
} 
characteristics. ${ }^{17}$ Finally, we cluster standard errors by country and use sample weights provided by Gallup to make the data representative at the country level.

\subsection{Instrumentation Strategy}

To identify the causal effects of international trade on political approval, we need to address the issues of omitted variables bias and reverse causality. If individuals do not approve of the performance of their leader or do not have confidence in the government, that might affect economic activity and eventually influence the volume and composition of trade. Trade and political outcomes may also be jointly affected by omitted variables (such as a change in institutions). Furthermore, measurement error in high skill intensive exports (imports) may result in attenuation bias. To tackle these issues, we use two-stage least squares (2SLS) methodology with instrumental variables that affect high skill intensive exports (imports) but are unrelated to the approval of or confidence in the incumbents.

To find a valid instrument, we focus on exogenous determinants of trade flows that predict each country's high skill intensive exports and imports. Specifically, we use the changes in high skill intensive bilateral trade flows that have resulted from advances in transportation technology. ${ }^{18}$ As documented in Hummels (2007), substantial improvements in technology have sharply cut the cost of air shipping relative to that of sea shipping. Put differently, a weight/value ratio of trade for air transport has been declining much faster than a weight/value ratio of trade for sea transport. Trade costs have therefore changed differently for country pairs with different sea-distance-to-air-distance ratios. This means, for instance, that countries located far in terms of sea distance from their major export markets - but close to

\footnotetext{
${ }^{17}$ Our results are also robust to inclusion of country-year fixed effects.

${ }^{18}$ In a similar way, Pascali (2017) uses the adoption of the steamship in the late $19^{\text {th }}$ century to establish a causal relationship between trade and development, exploiting the differential impact of this new technology on trade between countries separated by larger or smaller technology-specific travel time.
} 
them in terms of air distance - have a comparative advantage in lightweight goods due to air shipping (Harrigan 2010).

As Figure 2 documents, the total unit cost of air freight fell substantially during our sample period (by 59 per cent between 2005 and 2015) while the unit cost of sea freight increased (by 47 per cent between 2005 and 2015). In line with this, total air freight traffic worldwide rose sharply, from 152 billion tonne-kilometers in 2005 to 199 billion tonne-kilometers in 2015, according to annual global statistics from ICAO (2015). Our identification strategy assumes that high skill intensive products are mostly light — and therefore usually transported by air — while low and medium skill intensive products are heavier — and therefore are usually transported by sea. But is this the case? If so, the shipping costs of high skill intensive products should be more sensitive to the air distance between the exporter and importer, while the shipping costs of low skill intensive products should be more sensitive to the sea distance between them. To check this, we estimated the following equation at the country pair-year-product level:

$$
\log \left(\operatorname{TrCost}_{\mathrm{ijt}}\right)=\alpha_{\mathrm{st}} \log \left(\text { SeaDistance }_{\mathrm{ij}}\right)+\alpha_{\mathrm{at}} \log \left(\text { AirDistance }_{\mathrm{ij}}\right)+\mathrm{D}_{\mathrm{ij}}+\mathrm{P}_{\mathrm{p}}+\varepsilon_{\mathrm{ijt}}
$$

where TrCost $\mathrm{ijtp}_{\mathrm{it}}$ is the transport cost (in dollars) to export one kilogram of product $p$ from exporting country $i$ to importing country $j$ in year $t .{ }^{19} \mathrm{D}_{\mathrm{ij}}$ represents bilateral pair fixed effects, which means the relationship is identified on the basis of withinpair changes; $\mathrm{P}_{\mathrm{p}}$ are product fixed effects; SeaDistance ${ }_{\mathrm{ij}}$ is the shortest bilateral sea trade distance, and AirDistance ${ }_{i j}$ is the weighted great circle distance between

19 Due to limited availability of data on transport costs around the world, we use an indirect measure - the difference between the "free on board" (FOB) value of goods when they are exported and the "cost of insurance and freight" (CIF) value of the same goods when declared by the importer. (Thus, we exploit the fact that each trade flow is counted twice, at the customs offices of both the exporter and the importer. Data on these flows are from CEPII and Berthou and Emlinger (2011)). CIF unit values rely on importers' declarations and include all trade costs (except tariffs and domestic taxes after the border). FOB unit values measure the trade price at the factory gate, relying on exporters' declarations, and do not include transportation costs (Berthou and Emlinger 2011). The difference between CIF and FOB unit values for the same good serves as our proxy for transportation costs. Strictly speaking, it includes insurance costs as well, but if, as seems likely, unit insurance costs did not change much during this period, the change in this proxy will measure mostly change in transportation costs. 
countries $i$ and $j$. Robust standard errors are clustered at the origin-destination pair level.

We estimated equation (2) separately for high skill intensive and low skill intensive products. ${ }^{20}$ If high skill intensive goods are transported by air and not by sea, $\alpha_{\mathrm{a}}$ should be positive and significant in the regression for the subsample of high skill intensive products, while $\alpha_{\mathrm{s}}$ should be zero. If low skill intensive goods are transported by sea and not by air, $\alpha_{a}$ should be zero in the regression for the subsample of low skill intensive products, while $\alpha_{\mathrm{s}}$ should be positive and significant. This is exactly what we find (see Figures 3 and 4). The results indicate that high skill intensive trade flows are, as supposed, sensitive to air distances and not to sea distances, while the opposite is true for low and medium skill intensive trade flows.

This allows us to construct an instrument for actual high skill intensive trade flows on the basis of geography. Our approach is based on the gravity model (Anderson, 2011 and Anderson and van Wincoop, 2003) and closely follows Feyrer (2009), Blanchard and Olney (2017) and Tabellini and Magistretti (2020). We begin by constructing estimates of "predicted trade flows" of high skill intensive products. Formally, we estimate the following equation:

$$
\log \left(\mathrm{X}_{\mathrm{ijt}}\right)=\beta_{\text {sea, },} \log \left(\text { SeaDistance }_{\mathrm{ij}}\right)+\beta_{\text {air, }} \log \left(\text { AirDistance }_{\mathrm{ij}}\right)+\mathrm{T}_{\mathrm{t}}+\mathrm{D}_{\mathrm{ij}}+\varepsilon_{\mathrm{ijt}}
$$

where $\mathrm{X}_{\mathrm{ijt}}$ is either (a) the bilateral flow of high skill intensive exports from exporter $i$ to importer $j$ in year $t$ or (b) the bilateral flow of high skill intensive imports to importer $i$ from exporter $j$ in year $t$. $\mathrm{T}_{\mathrm{t}}$ indicates year dummies. As in Equation (2), $\mathrm{D}_{\mathrm{ij}}$ represents bilateral pair fixed effects, which means the relationship is identified on the basis of within-pair changes in high skill intensive trade; SeaDistance $i j$ is the shortest bilateral sea trade distance, and AirDistance $i j$ is the weighted great circle

\footnotetext{
${ }^{20}$ We use correspondence tables provided by the World Integrated Trade Solution (WITS) to classify each product by its skill intensity.
} 
distance between countries $i$ and $j .{ }^{21}$ Here, $\beta_{\text {sea, }}$ is a vector of coefficients capturing the effect of sea distance in each year, while $\beta_{\text {air,t }}$ is a similar vector capturing the effect of air distance in each year.

From Equation (3), we calculate "predicted bilateral flows" of high skill intensive exports and imports for each country pair, based on their exogenous sea and air distances. ${ }^{22}$ We sum these across trading partners to construct our final instruments: the total predicted volume of high skill intensive exports (imports) of goods and services for each country. ${ }^{23}$ We use these two instruments - the total predicted volume of high skill intensive exports and the total predicted volume of high skill intensive imports - to create two predicted interaction terms: "the total predicted volume of high skill intensive exports*tertiary education" and "the total predicted volume of high skill intensive imports*tertiary education". In the final regression, we include these four variables. Our results are also robust to estimating effects separately for imports only and for exports only along with their interaction with the tertiary education dummy (i.e. not including both imports and exports in the same equation). ${ }^{24}$

As Figure 5 demonstrates, our instruments are good predictors of actual high skill intensive exports and imports. Since they are a function of only geography and time, they are exogenous with respect to political approval and therefore allow us to

\footnotetext{
${ }^{21}$ We also constructed alternatives instruments by controlling for country fixed effects and bilateral controls (whether the two countries are contiguous, share a common language, have ever had a colonial link, are currently in a colonial relationship, share a common language). IV specifications using these alternative measures also produce qualitatively similar results reports. These results are not reported but available upon request.

${ }^{22}$ It might seem strange that separate instruments can be constructed in this way for high skill intensive imports and high skill intensive exports. After all, each export from $i$ to $j$ is simultaneously an import to $j$ from $i$. In fact, however, the reported exports of one country rarely coincide exactly in a given year with the reported imports of its partner country. As the UN International Statistics explains, this occurs for a host of reasons including: time lags between exports and imports, goods passing through third countries, goods delayed in customs, different classification systems, and different trade systems.

${ }^{23}$ Since in our regressions the dependent variable is logged, we delog the estimates before summing them across trading partners and then take the log of the total for subsequent analysis. Our main models also include zero trade values. We tried excluding zero trade values and found qualitatively similar results (available on request).

${ }^{24}$ These results are reported in Appendix Table 17.
} 
identify causal effects. Following Feyrer (2009), our key identification assumption is that advances in air transportation technology are independent of any particular country and therefore contain no information about government or leader approval in specific countries.

It would be useful also to study the effect of low skill intensive trade on political approval. Unfortunately, when we construct instruments for low skill intensive exports and imports in the same way, the first stage F-statistics are below 4 in all models. While the instruments correlate with the relevant variable, the relationship is too weak to provide reliable identification (see Appendix Figures 1 and 2). This is expected given that low skill intensive goods are less likely to travel by air and, accordingly, less likely to be affected by change in relative air freight costs. In ordinary least squares specifications (see Appendix Tables 6 and 7), we found no relationship between low skill intensive exports and imports and differences in political approval between unskilled and skilled individuals, but lacking an identification strategy we must remain agnostic on this point.

\section{$5 \quad$ Results}

This section presents three sets of results. We first show Ordinary Least Squares (OLS) estimates. We then present IV results following the methodology introduced in section 4.2 and conduct a counterfactual analysis to illustrate the quantitative implications of our results. We also investigate heterogeneity by socio-economic subgroups and country income levels. Finally, we present a set of robustness checks.

\subsection{Ordinary Least Squares Specifications}

In this subsection, we start by analysing the effects of international trade on political approval among skilled workers relative to unskilled workers. Table 2 presents the results from the OLS estimation where the dependent variable is a dummy variable 
indicating that the respondent approves of "the job performance of the leadership of his or her country" and Table 3 presents the results from the OLS estimation where the dependent variable is a dummy variable indicating that the respondent has "confidence in national government."

In both tables, Column 1 reports the estimation with country and year fixed effects and country level controls (Polity 2 scores, press freedom index, the log of country population, and the log of GDP per capita) included; column 2 adds demographic characteristics; column 3 adds the logarithm of household income; column 4 adds country-specific linear time trends. ${ }^{25}$

In all columns of Table 2, there is a positive relationship, marginally significant at $\mathrm{p}<.01$, between total imports (which here captures the effect among the unskilled) and approval of the leader. Total imports are also positively related to approval of the government (among unskilled respondents) in all columns of Table 3, though these estimates are not statistically significant. Contrary to the conventional wisdom, we find no evidence that unskilled workers oppose imports and blame their leaders for failing to protect markets-rather the reverse. There is no sign that growth in total exports affects political approval one way or the other.

Although the association between increased total imports and higher approval is only significant among unskilled respondents, Tables 2 and 3 provide no evidence that skilled and unskilled individuals react differently to such growth. Nor do they respond differently to growth in total exports - none of the interaction terms is significant. When skilled and unskilled respondents are combined, the average effect of imports on approval is not significant (see Column 1 of Appendix Table 2). Nor are either high skill intensive imports or high skill intensive exports significantly associated with approval if respondents are not disaggregated by skill

\footnotetext{
${ }^{25}$ In results not reported but available upon request, we also included the log of imports/GDP ratio and the log of exports/GDP ratio in country level controls to check robustness. Our results remained qualitatively the same. Of course, these controls could be considered endogenous or post-treatment. Therefore, our preferred specification, Column 4 of Table 4 excludes them.
} 
level (see Column 2 of Appendix Table 2). These results highlight the need for a more granular approach analyzing the composition of trade.

Tables 4 and 5 present OLS estimates of the relationship between the total volume of high skill intensive exports (imports) and political approval among skilled individuals. In Table 4 we report results for approval of the leader's performance. The coefficients at the skill-intensive exports and imports variables are small and statistically insignificant; this implies no effect of skill-intensive trade on unskilled individuals. The interaction term between the tertiary education dummy and the logarithm of total high skill intensive exports in the first column is positive and statistically significant (with a magnitude of 0.045 ), and the interaction term between the tertiary education dummy and the log of total high skill intensive imports is negative and statistically significant (with a magnitude of -0.051). The former is the estimated impact of growth in high skill intensive exports on political approval among skilled individuals (relative to unskilled ones), and the latter is the estimated effect of growth in high skill intensive imports on political approval among skilled individuals.

Columns 2 to 4 show that the estimated effects are similar, and remain significant, as additional controls are added. In Column 5, we address possible concerns about "bad controls" (Angrist and Pischke, 2008). One might worry that some of the country characteristics and household income might themselves be affected by trade shocks. However, we show that excluding them does not substantively change the point estimates for our key education-related variables (this is also true for the IV estimates in Tables 8 and 9). We keep these controls in our baseline specification (that is, Column 4) to avoid omitted variable bias and to enhance comparability with results of previous work on, for instance, voting for populist parties in Europe.

In our fully saturated regression (Column 4), a 10 percent increase in high skill intensive exports leads to a 0.46 percentage point increase in confidence in the country's leader among the skilled relative to the unskilled. A 10 percent increase 
in high skill intensive imports results in a 0.53 percentage point fall in approval of the leader among skilled individuals (relative to unskilled ones). Table 5 reports the results for confidence in national government. The results have the same sign, statistical significance, and similar magnitudes.

We also checked whether trade shocks affected political preferences of unskilled individuals. Appendix Tables 6, 7, 8 and 9 present OLS estimates of the relationship between the total volume of low skill intensive exports (imports) and political approval among unskilled individuals. Irrespective of how we define unskilled (those with primary education or less, those with secondary education, those with secondary education or less), we do not find any evidence that increases in low skill intensive exports (imports) affect confidence in the country's government or leader among the unskilled relative to the skilled. Notably, these null results also do not change when we use alternative low skill intensive trade definitions. ${ }^{26}$ However, simple OLS results, which do not account for endogeneity, are hardly conclusive; since we are unable to instrument for low skill intensive trade, we must remain agnostic on this point.

\subsection{Instrumental Variables Specifications}

In this section, we present the IV estimates of the relationship between the composition of trade and political approval. We use the total predicted volume of high skill intensive exports (imports) as instrument for the total actual volume of high skill intensive exports (imports).

We first discuss the validity and the power of the instrument. Tables 6 and 7 present the first stage estimates, which show a strong relationship between the total predicted volume of skill intensive exports (imports) and the actual total volume of

\footnotetext{
${ }^{26}$ We used the following alternative definitions: (i) agriculture + labour intensive + low skill intensive exports and imports; (ii) labour intensive + low skill + medium skill intensive exports and imports; (iii) labour intensive + low skill intensive exports and imports; (iv): low skill + medium skill intensive exports and imports.
} 
high skill intensive exports (imports). This relationship is robust to the inclusion of individual-level covariates as well as country-level controls. Overall, the instruments are highly correlated with the relevant endogenous variables and have predictive power. The results for the first stage F-test also show that the first-stage relationships are strong for both individual regressions and joint significance of the instruments. The Kleiberberg-Paap F-statistic is 26 in the sample for which data on approval of the leader are available; for the sample with data on confidence in the national government, the F-statistic is 25 .

Tables 8 and 9 present the second-stage estimates, in which we replicate the OLS specifications from Tables 4 and 5. We only report coefficients on the main variables of interest. Column 4 of Table 8 presents the IV results with country and year fixed effects, country-specific linear time trends, household income and demographic characteristics, as well as time-varying country-level characteristics. The impact of skill intensive exports on approval of the leader among skilled individuals is positive and significant, with a point estimate of 0.116 , while that of skill intensive imports is negative and significant, with the point estimate $-0.165 .{ }^{27}$

The magnitudes imply that a 10 percent increase in skill-intensive exports results in a 1.2 percentage point increase in political approval among the skilled individuals (relative to the unskilled). The respective decrease for skill-intensive imports is 1.7 percentage points. In our dataset, the maximum deviation of skill-intensive exports from the country specific trend (averaged across all countries) was +3.4 percent; the minimum deviation was -3.0 percent. The numbers for skill-intensive imports are +3.0 and -2.6 percent respectively. Therefore, if we compare a year with maximum skill-intensive exports (in terms of deviation from the country trend) and

\footnotetext{
${ }^{27}$ One possible threat to identification might occur if changing fuel prices cause changes in exports and imports of high skill intensive products between given country pairs in a way that depends on their air and sea distances, and changing fuel prices also affect government approval through some other channel. We checked, however, that our results are robust to controlling for per capita oil revenue, oil prices, oil exports, oil production and their interactions with the high skilled dummy (Appendix Table 15 reports the results while controlling for per capita oil revenue. Other estimates are not reported but available upon request). The estimated effects are qualitatively and quantitatively similar to the baseline results in Column 4 of Tables 8 and 9.
} 
minimum skill-intensive imports with a year with minimum skill-intensive exports and maximum skill-intensive imports, the difference in approval comes to $0.117 *(3.4+3.0)+0.165 *(3.0+2.6)=1.7$ percentage points. This is substantial: the average absolute value of the deviation of approval from its country-specific trend is 2.9 percentage points.

Our results also show that skilled individuals are on average more likely to approve of their countries' leaders (controlling for trade). The coefficient at tertiary education is 1.22 , so an increase of the share of skilled individuals in the population by 10 percentage points should (on average) increase political approval by 12 percentage points.

We find similar results in Table 9, where the dependent variable is confidence in the national government. The impact of high skill intensive exports on confidence in national government among skilled individuals (relative to the unskilled) is positive and significant, with a magnitude of 0.113 (column 4). That of high skill intensive imports is negative and significant, with a point estimate of -0.152 . In each specification, the IV coefficients are larger than the OLS estimates. ${ }^{28}$

In Table 10, we provide examples to develop a better understanding of the quantitative implications of our results. Specifically, we choose four countries with relatively large increases in skill-intensive exports and four with large increases in skill-intensive imports over the sample period 2005-2015. Using the regression coefficients from our preferred 2SLS specification (Column 4 of Table 8), we predict the impact of these changes in trade on the approval rates of the country's leader among skilled respondents in the given country. We compare the predicted changes in approval to the actual changes in approval among the skilled over the same period. We find that for the countries with large increases in skill intensive

\footnotetext{
${ }^{28}$ There is no strong correlation between our instrument and low skill intensive exports and imports. This is not surprising as our instrument is based on the idea that skill intensive goods are more likely to be transported by air. This, however, makes it impossible to identify the causal effect of lowskilled trade on political approval.
} 
exports (Bulgaria, Lithuania, Nigeria, and Slovakia) trade effects explain a quarter of the increase in political approval among high skill individuals on average. For the countries with large increases in skill intensive imports (Chile, Paraguay, South Korea, and Turkey) trade effects explain from one half to two thirds of the actual decrease in political approval among high skill individuals.

To understand the heterogeneity of the effects, we consider the IV estimations for various subsamples. First-stage F-statistics for heterogeneity estimates are above 10 in all models, though to conserve space we do not report these. Table 11, which reruns the baseline specification in column 4 of Tables 8 and 9 for different subgroups, shows that there are no meaningful differences in responses between men and women and between younger and older cohorts. One might expect to find stronger effects in rural areas, where labor markets are less competitive and so workers have more to fear from trade shocks. ${ }^{29}$ Columns 1 and 2 in Table 12 confirm that this is, indeed, the case. Columns 3 through 5 show that low-income and middle-income households are more responsive to trade shocks and that the average results are mostly driven by these groups. For high-income households, coefficients have the same signs and are statistically significant, but the effects are smaller. ${ }^{30}$ The smaller effects for high-income individuals may be explained by the fact that our indicator for skilled workers (i.e. tertiary education) de facto includes the occupational dummies for professionals and executives, who are less likely to be hurt by the labour market effects of trade shocks.

We also estimate the relationship between trade and political approval separately for richer and poorer countries. Columns 1 and 2 of Table 13 show that the effect of high skill intensive exports on high skilled workers is almost twice as large in developing as in developed countries (for confidence in the government, the effects

\footnotetext{
${ }^{29}$ The share of skilled individuals living in rural areas in our estimation sample is 19 percent in developed countries and 7 percent in developing ones.

${ }^{30}$ The distribution of the share of skilled individuals by income-groups in our estimation sample is as follows: (i) for less developed countries: 0.03 in low-income tercile, 0.15 in middle-income tercile, 0.29 in upper-income tercile; (ii) for developed countries: 0.05 in low-income tercile, 0.14 in middle-income tercile, 0.33 in upper-income tercile.
} 
are comparable in size). We also show in Appendix Table 16, that the effect is driven primarily by the response of high-skilled workers in countries that import relatively more skill-intensive goods and export relatively fewer.

In Columns 3 and 4 of Table 13, we split the sample by the level of democracy. Specifically, Column 3 reports the estimates for less democratic countries (i.e. below sample median polity 2 score of 8 ) and Column 4 presents results for more democratic countries (above sample median polity 2 score of 8 or above). The effects seem to be similar in both democratic and less-democratic sample. In addition, we rank countries by returns to education (i.e. by estimating withincountry Mincer equations) in Appendix Table 14. The findings suggest that the middle-tercile group mostly drives the average results.

\subsection{Placebo and Robustness Checks}

Table 14 presents our placebo analysis. We examine responses to four parallel questions that should not, in theory, be affected directly by a change in trade flows - whether the respondent had confidence in the military, the judicial system, freedom of media, and honesty of elections. The results confirm that the significant relationships documented in Tables 8 and 9 are specific to political approval. We find no economically or statistically meaningful association between growth in high skill intensive exports (imports) and confidence in any of the other institutions.

Tables 15 and 16 present additional robustness checks. The top panel of Table 15 controls for individual unemployment - at the cost of restricting the sample to years after 2009. Notably, we find that unemployment leads to a 4.1 percentage point fall in confidence in the national government and 4.7 percentage point fall in approval of the leader. The bottom panel of Table 15 excludes election years to investigate whether strategic respondents distort the polls. The top panel of Table 16 controls for leaders' continuous tenure (since time in office can affect approval 
ratings) and the bottom panel of Table 16 lowers the minimum age in the sample to 15 years. The results remain qualitatively the same.

We also explore whether results differ in countries that are major recipients of offshoring business from advanced economies. Several papers suggest that in advanced economies, where offshoring means the loss of relatively low skill jobs, greater exposure to it fuels protectionism among low-skilled workers (Owen and Johnston 2017, Walter 2017). Less developed countries, by contrast, tend to gain jobs from offshoring by the advanced economies - and these tend to be jobs for workers who, within the less developed country, have relatively high skill levels. In such countries, therefore, greater offshoring should increase the support of high skill workers for economic openness.

With this in mind, we conjectured that among high-skilled workers in less developed countries access to outsourced jobs would reduce the sensitivity of political approval to trade in high skill-intensive products. First, such workers are protected by the availability of alternative, outsourced jobs. Second, offshoring goes along with participation in global value chains, which requires increases in imports as well as exports. High skill workers may accept increased imports of high skill intensive industrial inputs, realizing that they are essential to subsequent exports of higher value added outputs. If so, such increases in imports need not be politically unpopular.

We use the AT Kearney Global Services Location Index (2017) to determine the top 35 destination countries (excluding developed nations). The IV results are shown in Table 17. As expected, the coefficient on the interaction between tertiary education and high-skill imports (and exports) is no longer statistically significant in the destination countries and now has the "wrong" sign. This is consistent with the view that receiving outsourced jobs can insulate the educated population in 
developing countries against the costs of freer trade. ${ }^{31}$ The second column of Table 17 shows that the coefficients for the subsample of non-outsourcing developing countries are large and statistically significant.

In Table 18, we consider unemployment and individual income as economic outcomes to investigate a potential link between trade, labour market outcomes and political approval. OLS estimates in Column 1 suggest that increases in high skill intensive exports lead to a fall in unemployment among skilled individuals and growth in high skill intensive imports has the opposite effect. However, while the coefficients are similar in IV specifications (Column 2), they are no longer statistically significant. When it comes to individual income, we find that growth in high skill intensive exports increases income among skilled individuals, whereas growth in high skill intensive imports reduces income (Columns 3 and 4). These results provide suggestive evidence that labor market related shocks due to changes in trade structure do - as we have hypothesized - influence political approval.

Of course, the political effect of trade flows in a given year will depend upon what - if anything - the government does in response. If the leader is seen as fighting back against excessive imports by imposing tariffs, that might regain him support among those harmed. In Table 19, we therefore tried controlling for each country's average tariff. This did not affect our results. The point estimates on the average tariff rate were not statistically significant at conventional levels. Appendix Figure 3 also shows that average tariff rate fell from 8.69 in 2005 to 7.13 in 2015.

We have so far used completed tertiary education as our measure of high skills. But those with secondary education have significantly greater skills than those with primary school or less. Moreover, the proportions of the work force with different levels of education will vary across countries. We therefore tried running the same estimations including dummies for both tertiary and secondary education, along

\footnotetext{
${ }^{31}$ As a robustness check, we also tried using an alternative definition of "high-skilled individuals" in this estimation, including those with at least secondary education. The results do not change.
} 
with their interactions with high skill intensive exports (imports) in Table 20. The effect of secondary education and its interaction are positive and sometimes statistically significant, but smaller than those for tertiary education, which remain large. These results also confirm that our results are not driven by choosing an arbitrary education threshold.

The time period we study includes the global financial crisis and the associated short-lived collapse in world trade. Is the result driven by the-highly atypicalyears of the great recession? To check this, we tried excluding the recession years (2008-2010) and also dropping individual sub-periods (2005-2008, 2009-2011, and 2012-2015) one at a time (see Appendix Tables 10 and 11). Results remain similar.

Another possibility is that our results are picking up greater sensitivity among the more educated to economic performance in general rather than to trade per se. When economic performance is better, net exports tend to be higher. So our results could be driven by a greater tendency among the highly educated to praise or blame the government for current economic performance than among their less educated peers. To check this, we tried including an interaction of high skills with the logarithm of GDP per capita. Reassuringly, this does not substantively change any of our findings. And, in fact, the impact of GDP per capita on political approval is no higher among the more educated than among the less educated (see Appendix Table 12).

Finally, our findings do not change: (i) when we use the share of high skill intensive exports (imports) as a percentage of total exports (imports) instead of the log of total volume of high skill intensive export (imports) - reported in Appendix Tables 3 and 4 (the first stage F-statistics are above 26 in all specifications); (ii) when we define skilled as "secondary education or above" (Appendix Table 5); (iii) when we exclude the top one per cent income group; (iv) when we control for export/GDP and import/GDP ratios; (v) when we control for low skill intensive exports and 
imports; (vi) when we include country-specific quadratic time trends; and (vii) when we include country-skill fixed effects (Appendix Table 13).

\section{Conclusions}

Our results suggest that international trade shocks affect individuals' levels of support for incumbent leaders and governments. And they do so in a way that depends on the match between individuals' skill levels and the characteristics of the goods imported or exported. Analyzing data from 118 countries in 2005-15, we used an instrument based on geography to estimate the causal impact of changing skill intensity of imports and exports. We found that growth in high skill intensive exports increased approval of the incumbent government and leader among skilled respondents, while growth in high skill intensive imports had the opposite effect. High skill intensive trade did not affect political approval among the unskilled. The effects did not vary significantly with age or gender, but were stronger for rural residents, who often have fewer alternatives when local firms are forced to close. The effects disappear in countries that benefit from significant offshoring. There, access to alternative jobs outsourced from advanced economies and the opportunity to participate in global value chains apparently reconcile high skilled workers to economic openness.

Previous literature on the politics of trade has mostly concentrated on the effects of import shocks on low-skill workers in the developed West. Many blame such shocks for the recent surge of populist discontent across Europe and North America. In advanced economies, it is indeed low-skill workers who are most vulnerable to import competition, so policy responses usually focus on retraining. However, in developing and middle-income countries, trade shocks are likely to disproportionately harm more highly skilled workers. In such cases, additional training is no solution. On the contrary, it will make skilled workers displaced by imports even less employable in an economy increasingly specializing in low skill 
intensive exports. Since the highly educated also tend to be the most politically sophisticated and active, governments in such countries come under pressure to respond with skill-biased protectionist measures.

To take one example, unemployment has recently surged among the highly educated in India. The rate among those with college degrees more than doubled between 2011 and 2016, forcing millions of new graduates to settle for menial jobs (Slater 2019). This followed sharp cuts in the country's tariff rates: the weighted average tariff on manufactured products fell from 25 percent in 2004 to 7 percent in 2013, according to World Bank data. Prime Minister Narendra Modi responded by re-introducing tariffs on a range of skill intensive imported goods, such as electronics components (Aiyar 2018). Despite his image as an economic liberal, he has embraced protectionism since 2016, favoring creation of "national champions" in high-tech industry. He pioneered "phased manufacturing programs," which "use import duties and informal political pressure" to get major electronics firms to produce advanced goods and components within India (Ibid). Modi's ratings among skilled Indians-already high for other reasons-increased. ${ }^{32}$ Although various factors may explain this, his protectionist response to trade threats likely contributed.

India does not appear to be an exception. In poorer democracies, one might expect unskilled workers to be politically dominant because of their voting power. Yet, trade policy often seems to favor the highly skilled, who lobby effectively for protections. Between 1978 and 2002, trade barriers against low skill goods significantly decreased in a range of developing world democracies; at the same

\footnotetext{
${ }^{32}$ Modi's tenure falls mostly outside our GWP sample period, but recent Pew Global Attitudes surveys show his rating rising among the highly educated following these skill-biased protectionist policies. Between 2015 and 2017, the percentage of Indians with some college education who were "very favorable" towards Modi rose from 71 to 80 percent. The corresponding figure for those with primary education or less rose only 1 percent (from 65 to 66 percent) (see https://www.pewresearch.org/global/2015/09/17/1-the-modi-phenomenon/ and https://www.pewresearch.org/global/2017/11/15/support-for-prime-minister-modi-remainsstrong/, accessed on July 18, 2019).
} 
time, however, those against high skill goods remained constant or increased (Milner and Mukherjee 2013, p.3). Other countries with a noted high skill bias in protectionism include Brazil and South Africa.

As skill levels rise across the developing world, the combination of free trade for low skill goods with protection for high skill jobs will continue to seem tempting to many leaders. Since 2000, gross tertiary enrolment in middle income countries has soared from 14 percent to 36 percent, according to the World Bank. Simultaneously, in many of them unemployment among people with advanced education has increased: from 2 to 7 percent in Brazil, 7 to 15 percent in India, 2 to 7 percent in Pakistan, 6 to 12 percent in South Africa, and 10 to 12 percent in Turkey. ${ }^{33}$ The main alternative to protecting the high skill sector, our findings suggest, is to seek outsourced jobs from developed countries. To the extent that leaders can attract skill intensive production tasks or service sector jobs from advanced economies, that may help to contain the discontent of their more educated citizens.

\footnotetext{
${ }^{33}$ World Bank data, accessed Feb 12, 2020 (https://data.worldbank.org/indicator/). Latest figures are for 2018.
} 


\section{References}

Aiyar, Swaminathan. 2018. India's New Protectionism Threatens Gains from Economic Reform. Cato Institute Policy Analysis 851, October 18.

Algan, Y., Guriev, S., Papaioannou, E. and Passari, E., 2017. The European trust crisis and the rise of populism. Brookings Papers on Economic Activity, 2017(2), pp.309-400.

Anderson, J.E., 2011. The gravity model. Annual Review of Economics, 3(1), pp.133-160.

Anderson, J.E. and Van Wincoop, E., 2003. Gravity with gravitas: a solution to the border puzzle. American Economic Review, 93(1), pp.170-192.

Autor, D., Dorn, D. and Hanson, G.H., 2013. The China Syndrome: Local labor Market Effects of Import Competition in the United States. American Economic Review, 103(6), pp.2121-68.

Autor, D., Dorn, D., Hanson, G. and Majlesi, K., 2016. Importing political polarization? the electoral consequences of rising trade exposure (No. w22637). National Bureau of Economic Research.

Baldwin, R., 2008. The Development and Testing of Heckscher-Ohlin Trade Models: A Review. MIT Press.

Bernard, A.B., Jensen, J.B., Redding, S.J. and Schott, P.K., 2007. Firms in international trade. Journal of Economic Perspectives, 21(3), pp.105-130.

Berthou, A. and Emlinger, C., 2011. The trade unit values database. Economie internationale, (4), pp.97-117. 
Blanchard, E.J. and Olney, W.W., 2017. Globalization and human capital investment: Export composition drives educational attainment. Journal of International Economics, 106, pp.165-183.

Bombardini, Matilde, 2008. Firm heterogeneity and lobby participation. Journal of International Economics 75.2, pp. 329-348.

Burstein, Ariel, and Jonathan Vogel. 2017. "International trade, technology, and the skill premium." Journal of Political Economy 125(5): 1356-1412.

Che, Y., Lu, Y., Pierce, J. R., Schott, P. K., \& Tao, Z., 2016. Does trade liberalization with China influence US elections? National Bureau of Economic Research, w22178.

Colantone, I., Crinò, R. and Ogliari, L., 2015. The Hidden Cost of Globalization: Import Competition and Mental Distress. CEPR Discussion Paper No: 10874.

Colantone, I. and Stanig, P., 2016. Global Competition and Brexit, Baffi Carefin No. 44.

Colantone, I. and Stanig, P., 2017. The trade origins of economic nationalism: Import competition and voting behavior in western Europe. Baffi Carefin Centre Research Paper Series No: 49.

Cruz, Cesi, Philip Keefer and Carlos Scartascini. 2016. Database of Political Institutions Codebook, 2015 Update. Washington, DC: Inter-American Development Bank.

De Vries, C.E., 2017. The Cosmopolitian-Parochial Divide: What the 2017 Dutch Election Result Tells Us About Political Change in the Netherlands and Beyond. Journal of European Public Policy, forthcoming. 
Dippel, C., Gold, R. and Heblich, S., 2015. Globalization and its (dis-) content: Trade shocks and voting behavior (No. w21812). National Bureau of Economic Research.

Feyrer, J., 2009. Trade and income: exploiting time series in geography (No. w14910). National Bureau of Economic Research.

Fouquin, M. and Hugot, J., 2016. Back to the future: International trade costs and the two globalizations. CEPII Document de travail, (2016-13).

Hainmueller, Jens, and Michael J. Hiscox. 2006. "Learning to Love Globalization: Education and Individual Attitudes Toward International Trade." International Organization 60 (2):469-98.

ICAO (2015). The World of Air Transport. https://www.icao.int/annual-report2015/Pages/the-world-of-air-transport-in-2015.aspx

Guriev, S. and Treisman D., 2017. "The popularity of authoritarian leaders: An empirical investigation." Mimeo, UCLA.

Harrigan, J., 2010. Airplanes and comparative advantage. Journal of International Economics, 82(2), pp.181-194.

Hummels, D., 2007. Transportation costs and international trade in the second era of globalization. The Journal of Economic Perspectives, 21(3), pp.131-154.

Jensen, J.B., Quinn, D.P. and Weymouth, S., 2017. Winners and losers in international trade: The effects on US presidential voting. International Organization, pp.1-35.

Kim, In Song. "Political cleavages within industry: Firm-level lobbying for trade liberalization." American Political Science Review 111.1 (2017): 1-20. 
Mansfield, E.D. and Mutz, D.C., 2009. Support for free trade: Self-interest, sociotropic politics, and out-group anxiety. International Organization, 63(3), pp.425-457.

Margalit, Y., 2011. Costly jobs: Trade-related layoffs, government compensation, and voting in US elections. American Political Science Review, 105(1), pp.166188.

Margalit, Y., 2017. Commerce \& Oppositions: The Political Responses of Globalization's Losers. Mimeo, Stanford University.

Mayda, A.M. and Rodrik, D., 2005. Why are some people (and countries) more protectionist than others? European Economic Review, 49(6), pp.1393-1430.

Mayer, J., Butkevicius, A., Kadri, A. and Pizarro, J., 2003. Dynamic products in world exports. Review of World Economics, 139(4), pp.762-795.

Melitz MJ. 2003. The impact of trade on intra-industry reallocations and aggregate industry productivity. Econometrica 71(6): 1695-725.

Milner, Helen and Bumba Mukherjee. 2013. "Democracy, Globalization and the Skill-Bias in Trade Policy in Developing Countries," presented at Annual Meeting of American Political Science Association, Chicago.

Mion, G. and Zhu, L., 2013. Import Competition from and Offshoring to China: A Curse or Blessing for Firms?. Journal of International Economics, 89(1), pp.202215.

Murray M. W., 2016. Economies of Scale in Container Ship Costs. Mimeo, United States Merchant Marine Academy.

Owen, Erica \& Noel Johnston. 2017. "Occupation and the Political Economy of Trade: Job Routineness, Offshorability, and Protectionist

Sentiment." International Organization 71(4): 665-699. 
O'Rourke, K.H. and Sinnott, R., 2001. What determines attitudes towards protection? Some cross-country evidence. In Brookings Trade Forum (Vol. 2001, pp. 157-206).

Osgood, I., Tingley, D., Bernauer, T., Kim, I. S., Milner, H. V., \& Spilker, G., 2017. The charmed life of superstar exporters: Survey evidence on firms and trade policy. The Journal of Politics, 79(1), 133-152.

Pascali, L., 2017. The wind of change: Maritime technology, trade, and economic development. American Economic Review, 107(9), pp.2821-54.

Rho, Sungmin, and Michael Tomz. 2017. "Why don't trade preferences reflect economic self-interest?" International Organization 71(1): 85-108.

Rogowski, R., 1989. Commerce and coalitions: How trade affects domestic political alignments. Princeton, NJ, pp.1965-1985.

Scheve, K.F. and Slaughter, M.J., 2001. What determines individual trade-policy preferences? Journal of International Economics, 54(2), pp.267-292.

Slater, Joanna. 2019. “India’s Railroads Had 63,000 Job Openings. 19 Million People Applied." Washington Post, January 4.

Tabellini, M. and Magistretti, G., 2020. Economic Integration and Democracy: An Empirical Investigation. CEPR Discussion Paper No: 14336.

The Economist, 2016. "Drawbridges up." https://www.economist.com/news/briefing/21702748-new-divide-rich-countriesnot-between-left-and-right-between-open-and United Nations, 2002. Manual on Statistics of international trade in services. United Nations Publications, Statistical Paper, Series M, No. 86. 
Utar, H., 2018. Workers Beneath the Floodgates: Low-Wage Import Competition and Workers' Adjustment. Review of Economics and Statistics, Vol. 100, 631-647.

Walter, Stefanie. 2017. "Globalization and the Demand-Side of Politics: How Globalization Shapes Labor Market Risk Perceptions and Policy Preferences." Political Science Research and Methods 5 (1):55-80. 
Figure 1: Trends in Outcome Variables

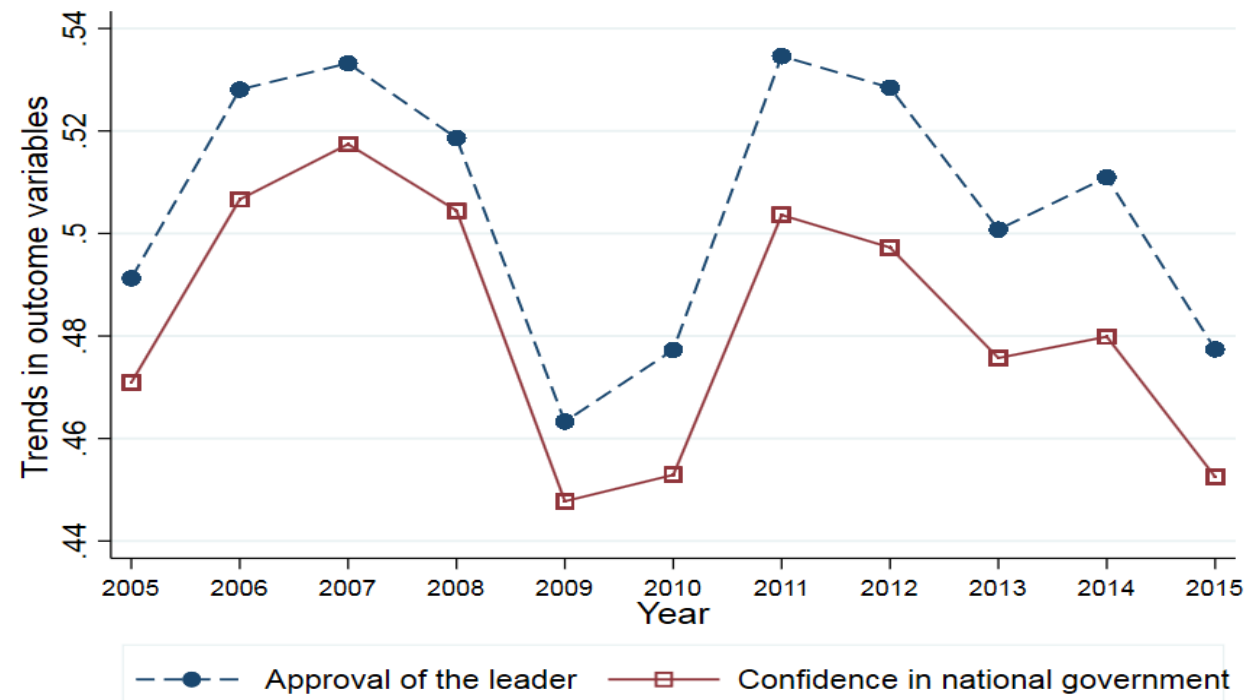

Source: Gallup World Polls, 2005-2015. Note: This figure includes all countries that were observed during at least 7 years of the sample. We further restrict the sample to observations used in the full-sample estimation. 
Figure 2: Change in Operating Cost for Aircrafts and Ships, 2005-2015

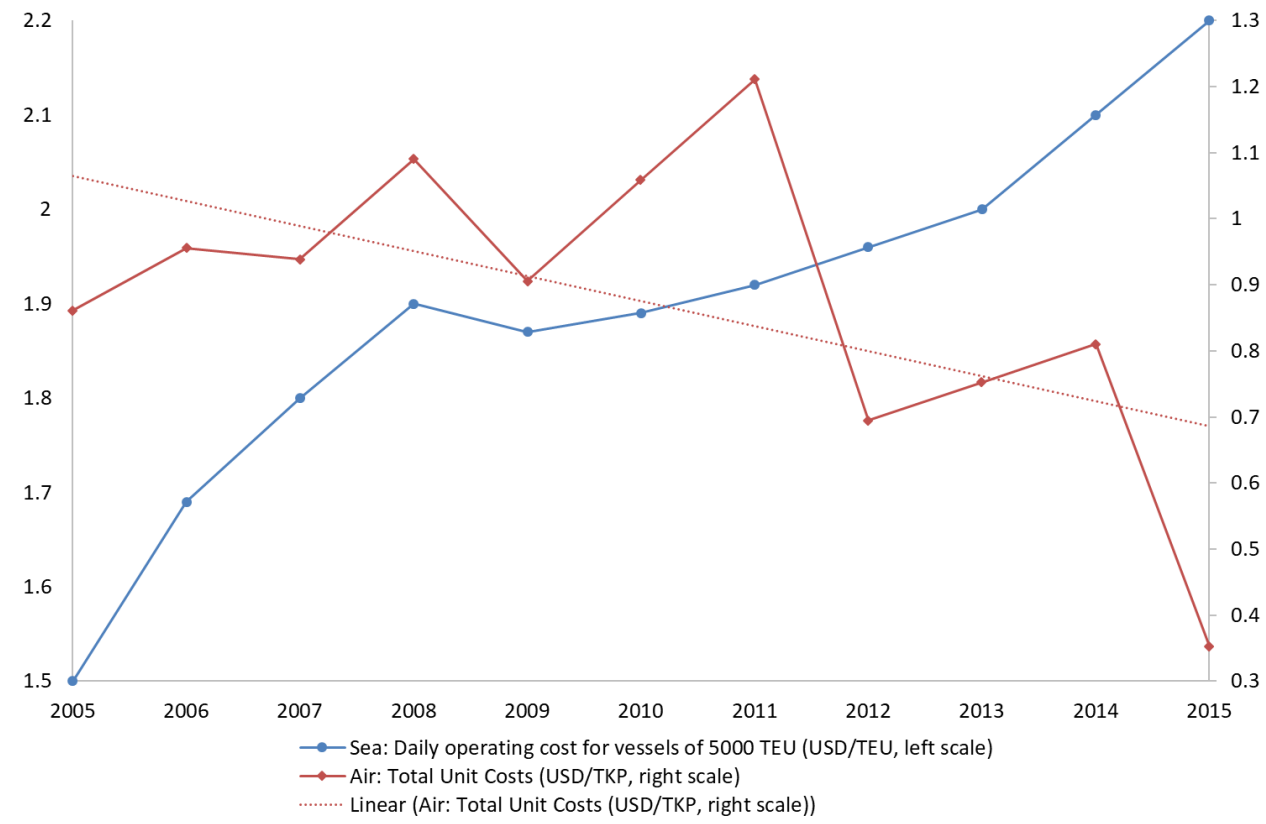

Source: Drewry, Murray (2016) and International Aviation Organization Database. Notes: Vessels operating costs often measured as the cost per Twenty-Foot Equivalent (TEU) per day and TEU is the standard unit for describing a ship's container carrying capacity. The graph above shows the average daily operating cost per TEU for vessels that can carry 5000 TEU. A tonne-km performed is a unit of measure of freight transport, which represents the transport of one tonne of goods by air, over a distance of one kilometre. The straight line is a linear time trend for the total unit cost of air transportation. 
Figure 3: Yearly Elasticity of Trade Costs (CIF-FOB) for High Skill Intensive Trade

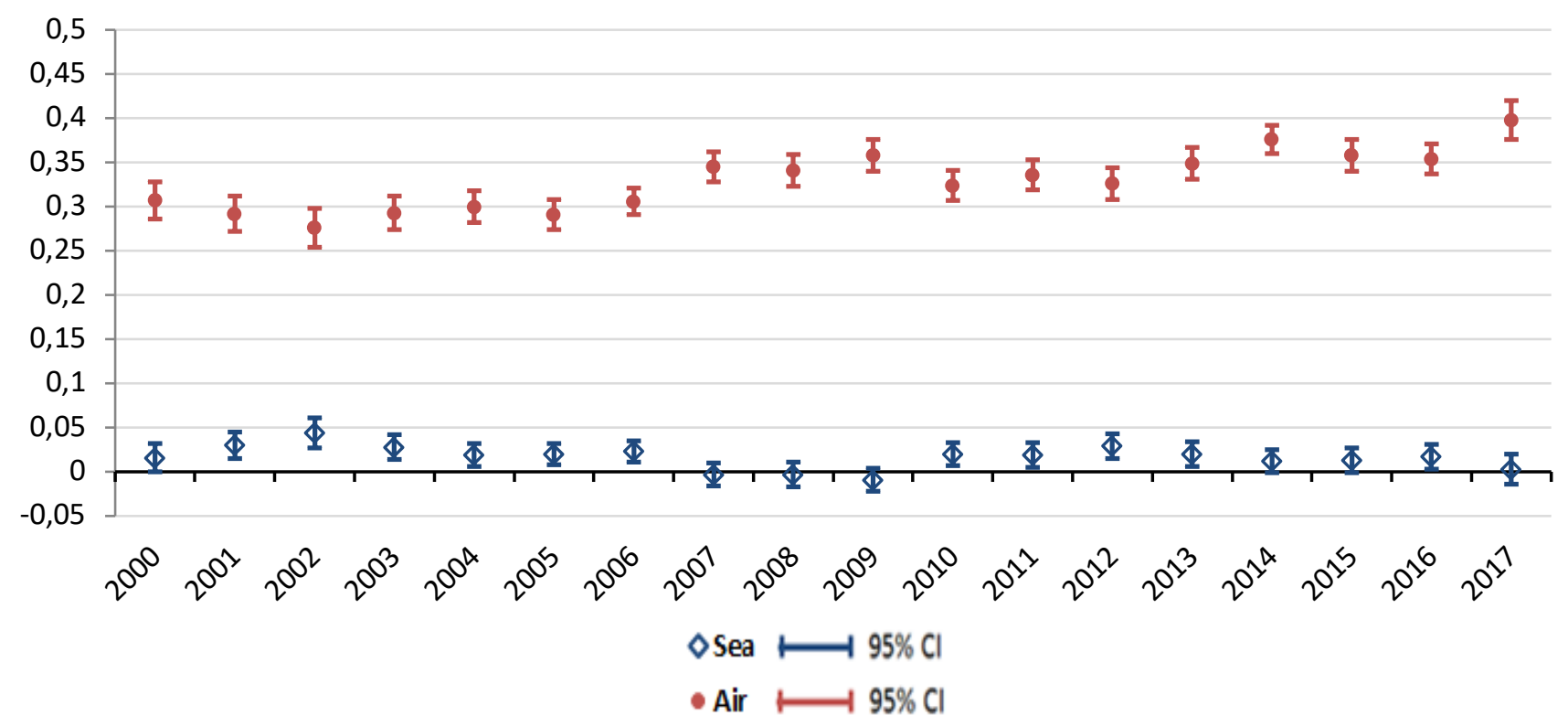

Notes: Point estimates of coefficients $\alpha_{s}$ and $\alpha_{a}$ at sea and air distance in the equation (2) for each year.

Figure 4: Yearly Elasticity of Trade Costs (CIF-FOB) for Medium + Low Skill Intensive Trade

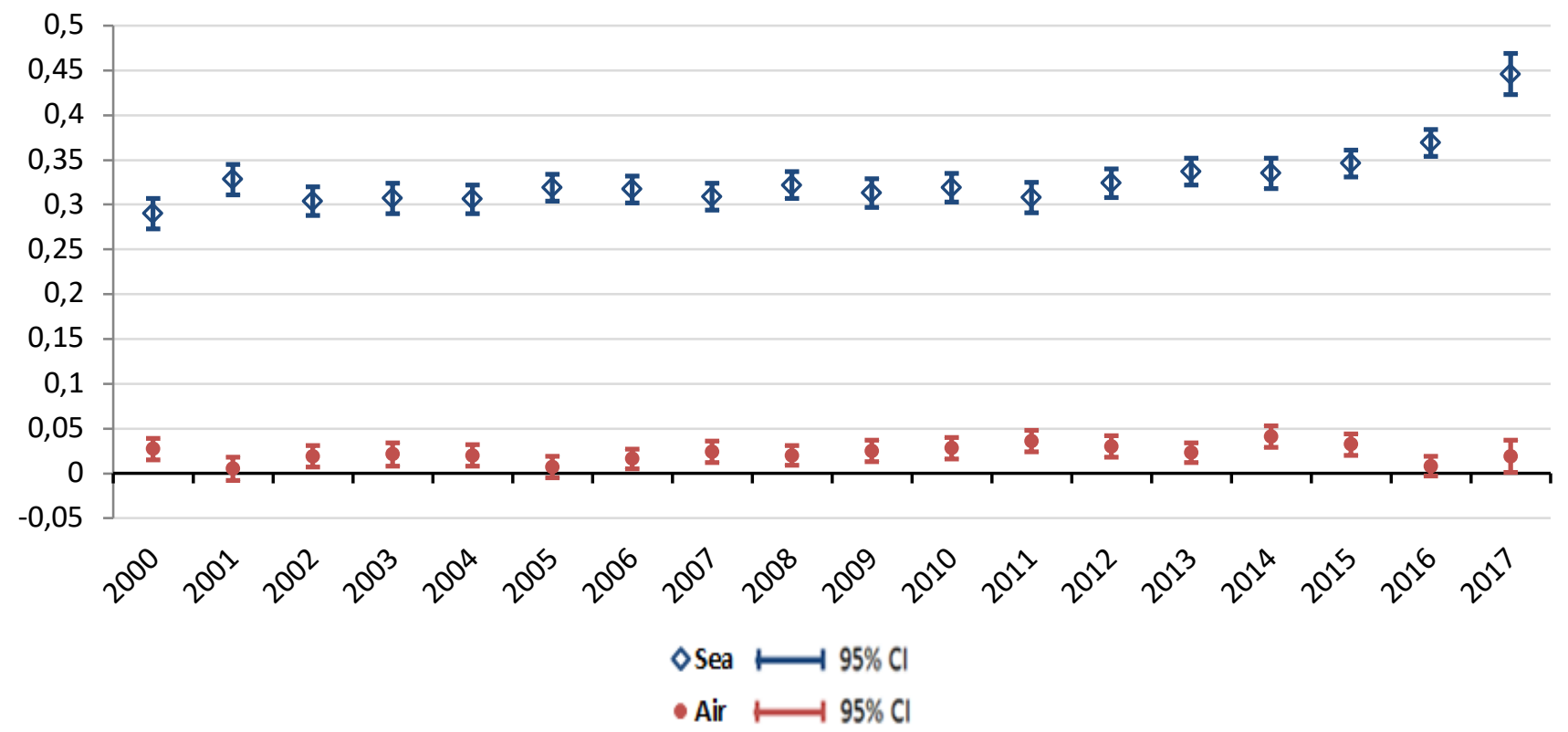

Notes: Point estimates of coefficients $\alpha_{s}$ and $\alpha_{a}$ at sea and air distance in the equation (2) for each year. 
Figure 5: Exports vs. Predicted Exports and Imports vs. Predicted Imports
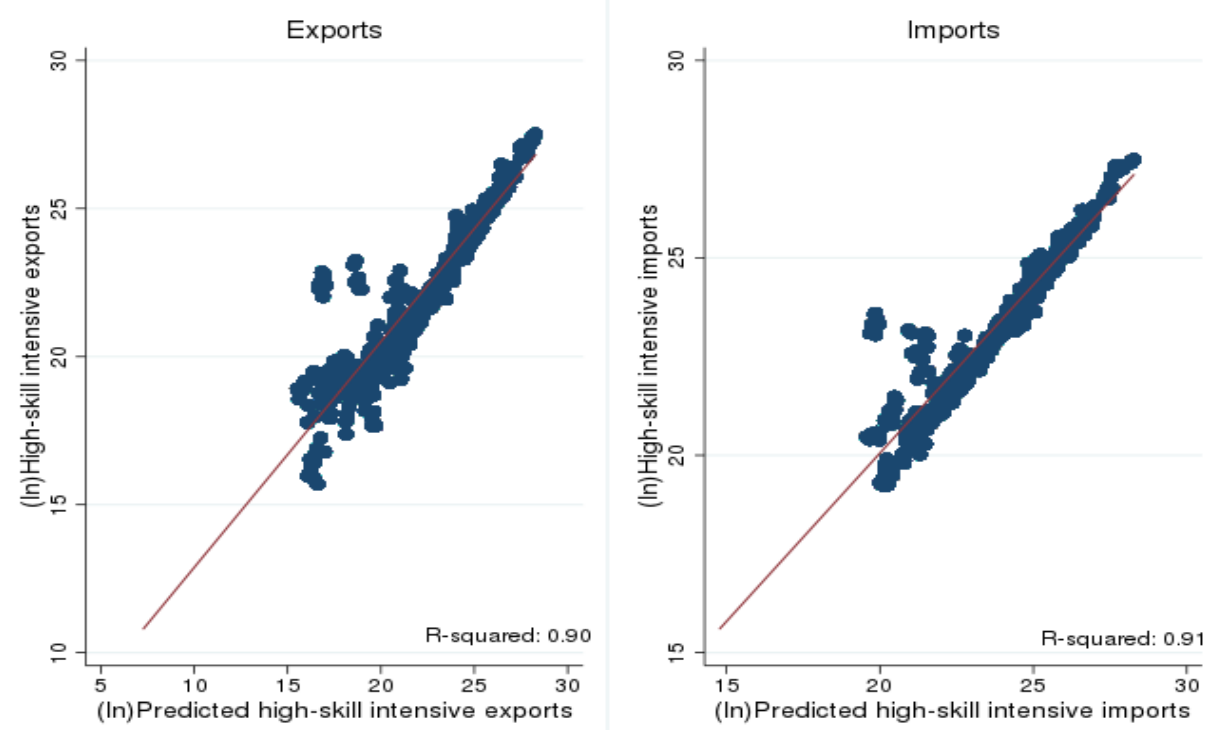

Notes: The left panel plots actual high-skill intensive exports against predicted high-skill intensive exports. The right panel plots actual high-skill intensive imports against predicted high-skill intensive imports. 
Table 1: Sample Characteristics - 2005-2015 Gallup World Poll Data

(1)

Variables
Dependent variables

Approval of the leader

Confidence in national government

Mean (Standard deviation)

$0.49(0.49)-\mathrm{N}: 426132$

$0.48(0.49)-\mathrm{N}: 459986$

International trade characteristics

Ln (Total High Skill Intensive Exports)

$22.75(2.80)$

Ln (Total High Skill Intensive Imports)

$23.50(2.08)$

Placebo outcomes

Have confidence in the military

Have confidence in the honesty of elections

Have confidence in the judicial system

Have confidence in the media

$0.72(0.44)-\mathrm{N}: 440141$

$0.49(0.49)-\mathrm{N}: 445397$

$0.50(0.49)-\mathrm{N}: 446528$

$0.53(0.49)-\mathrm{N}: 190270$

Individual level characteristics

Age

42.57 (11.30)

Male

$0.45(0.49)$

Tertiary education

$0.19(0.39)$

Partnered

$0.71(0.45)$

Urban

$0.53(0.49)$

Household income

$27,836(119,324)$

Country characteristics

Polity 2

$5.54(5.72)$

Press freedom index

$45.86(22.43)$

Import to GDP Ratio

$0.43(0.26)$

Export to GDP Ratio

$0.41(0.29)$

GDP Per Capita

$16,721(19,435)$

Ln (Country Population)

$17.03(1.77)$

$\mathrm{N}$

598100

Notes: Means (standard deviations). This table provides individual and aggregate level variables averaged across the 11 years (2005-2015) used in the analysis. The sample sizes for some variables are different either due to missing data or because they were not asked in every year. 
Table 2: OLS Estimates with Aggregate Exports (Imports) and Tertiary Education Interactions

\begin{tabular}{|c|c|c|c|c|}
\hline & $\begin{array}{c}(1) \\
\text { OLS }\end{array}$ & $\begin{array}{c}(2) \\
\text { OLS }\end{array}$ & $\begin{array}{c}(3) \\
\text { OLS }\end{array}$ & $\begin{array}{c}(4) \\
\text { OLS }\end{array}$ \\
\hline \multicolumn{5}{|l|}{ Outcome: Approval of the leader } \\
\hline TertiaryEducation*LogTotalExports & $\begin{array}{c}0.010 \\
(0.017)\end{array}$ & $\begin{array}{c}0.008 \\
(0.016)\end{array}$ & $\begin{array}{c}0.009 \\
(0.016)\end{array}$ & $\begin{array}{c}0.010 \\
(0.016)\end{array}$ \\
\hline Log Total Exports & $\begin{array}{c}0.023 \\
(0.022)\end{array}$ & $\begin{array}{c}0.022 \\
(0.022)\end{array}$ & $\begin{array}{c}0.022 \\
(0.022)\end{array}$ & $\begin{array}{c}0.016 \\
(0.036)\end{array}$ \\
\hline TertiaryEducation*LogTotalImports & $\begin{array}{c}-0.004 \\
(0.019)\end{array}$ & $\begin{array}{l}-0.003 \\
(0.019)\end{array}$ & $\begin{array}{c}-0.003 \\
(0.019)\end{array}$ & $\begin{array}{c}-0.005 \\
(0.019)\end{array}$ \\
\hline Log Total Imports & $\begin{array}{l}0.120 * \\
(0.066)\end{array}$ & $\begin{array}{l}0.120 * \\
(0.066)\end{array}$ & $\begin{array}{l}0.120 * \\
(0.066)\end{array}$ & $\begin{array}{l}0.166^{*} \\
(0.087)\end{array}$ \\
\hline Tertiary Education & $\begin{array}{l}-0.144 \\
(0.117)\end{array}$ & $\begin{array}{l}-0.129 \\
(0.114)\end{array}$ & $\begin{array}{c}-0.136 \\
(0.114)\end{array}$ & $\begin{array}{l}-0.116 \\
(0.114)\end{array}$ \\
\hline R-squared & 0.113 & 0.114 & 0.114 & 0.131 \\
\hline $\mathrm{N}$ & 426132 & 426132 & 426132 & 426132 \\
\hline Country fixed effects & Yes & Yes & Yes & Yes \\
\hline Year fixed effects & Yes & Yes & Yes & Yes \\
\hline Country level characteristics & Yes & Yes & Yes & Yes \\
\hline Demographic characteristics & No & Yes & Yes & Yes \\
\hline Household income & No & No & Yes & Yes \\
\hline Country-specific linear time trends & No & No & No & Yes \\
\hline
\end{tabular}

Notes: * significant at 10\%; $* *$ significant at 5\%;*** significant at $1 \%$. All specifications include multiple language and interview type dummies, though we do not report them above. Country characteristics include: Polity 2, press freedom index, the log of country population, and the log of GDP per capita. Demographic characteristics include: a male dummy, age and its square, dummy variables for marital status (married/civil partnership and divorced/separated), a dummy variable for living in an urban area and presence of children in the household (any child under 15). Household income includes all wages and salaries in the household, remittances from family members living elsewhere, and all other sources before taxes. Gallup converts local income to International Dollars using the World Bank's individual consumption PPP conversion factor, which makes it comparable across all countries. Results use the Gallup sampling weights and robust standard errors are clustered at the country level. 
Table 3: OLS Estimates with Aggregate Exports (Imports) and Tertiary Education Interactions

\begin{tabular}{|c|c|c|c|c|}
\hline & $\begin{array}{l}(1) \\
\text { OLS }\end{array}$ & $\begin{array}{c}(2) \\
\text { OLS }\end{array}$ & $\begin{array}{c}(3) \\
\text { OLS }\end{array}$ & $\begin{array}{c}(4) \\
\text { OLS }\end{array}$ \\
\hline \multicolumn{5}{|l|}{ Outcome: Confidence in Government } \\
\hline TertiaryEducation*LogTotalExports & $\begin{array}{c}0.013 \\
(0.017)\end{array}$ & $\begin{array}{c}0.012 \\
(0.017)\end{array}$ & $\begin{array}{c}0.012 \\
(0.017)\end{array}$ & $\begin{array}{c}0.010 \\
(0.017)\end{array}$ \\
\hline Log Total Exports & $\begin{array}{c}0.014 \\
(0.019)\end{array}$ & $\begin{array}{c}0.016 \\
(0.019)\end{array}$ & $\begin{array}{c}0.016 \\
(0.019)\end{array}$ & $\begin{array}{c}0.048 \\
(0.032)\end{array}$ \\
\hline TertiaryEducation*LogTotalImports & $\begin{array}{c}0.001 \\
(0.020)\end{array}$ & $\begin{array}{c}0.002 \\
(0.019)\end{array}$ & $\begin{array}{c}0.002 \\
(0.019)\end{array}$ & $\begin{array}{c}0.004 \\
(0.019)\end{array}$ \\
\hline Log Total Imports & $\begin{array}{c}0.052 \\
(0.054)\end{array}$ & $\begin{array}{c}0.052 \\
(0.054)\end{array}$ & $\begin{array}{c}0.052 \\
(0.054)\end{array}$ & $\begin{array}{c}0.092 \\
(0.073)\end{array}$ \\
\hline Tertiary Education & $\begin{array}{c}-0.353^{* * *} \\
(0.129)\end{array}$ & $\begin{array}{c}-0.325^{* *} \\
(0.127)\end{array}$ & $\begin{array}{c}-0.323^{* * *} \\
(0.127)\end{array}$ & $\begin{array}{c}-0.317 * * * \\
(0.120)\end{array}$ \\
\hline R-squared & 0.127 & 0.130 & 0.130 & 0.142 \\
\hline $\mathrm{N}$ & 459986 & 459986 & 459986 & 459986 \\
\hline Country fixed effects & Yes & Yes & Yes & Yes \\
\hline Year fixed effects & Yes & Yes & Yes & Yes \\
\hline Country level characteristics & Yes & Yes & Yes & Yes \\
\hline Demographic characteristics & No & Yes & Yes & Yes \\
\hline Household income & No & No & Yes & Yes \\
\hline Country-specific linear time trends & No & No & No & Yes \\
\hline
\end{tabular}

Notes: * significant at $10 \% ; * *$ significant at $5 \% ; * * *$ significant at $1 \%$. All specifications include multiple language and interview type dummies, though we do not report them above. Country characteristics include: Polity 2, press freedom index, the log of country population, and the log of GDP per capita. Demographic characteristics include: a male dummy, age and its square, dummy variables for marital status (married/civil partnership and divorced/separated), a dummy variable for living in an urban area and presence of children in the household (any child under 15). Household income includes all wages and salaries in the household, remittances from family members living elsewhere, and all other sources before taxes. Gallup converts local income to International Dollars using the World Bank's individual consumption PPP conversion factor, which makes it comparable across all countries. Results use the Gallup sampling weights and robust standard errors are clustered at the country level. 
Table 4: OLS Estimates with High-skill Intensive Exports (Imports) and Tertiary Education Interactions

\begin{tabular}{|c|c|c|c|c|c|}
\hline & $\begin{array}{l}(1) \\
\text { OLS }\end{array}$ & $\begin{array}{l}(2) \\
\text { OLS }\end{array}$ & $\begin{array}{c}\text { (3) } \\
\text { OLS }\end{array}$ & $\begin{array}{c}(4) \\
\text { OLS }\end{array}$ & $\begin{array}{c}(5) \\
\text { OLS }\end{array}$ \\
\hline \multicolumn{6}{|l|}{ Outcome: Approval of the leader } \\
\hline TertiaryEducation*LogHighSkillIntensiveExports & $\begin{array}{c}0.045^{* * *} \\
(0.007)\end{array}$ & $\begin{array}{c}0.044 * * * \\
(0.007)\end{array}$ & $\begin{array}{c}0.044^{* * *} \\
(0.007)\end{array}$ & $\begin{array}{c}0.046^{* * *} \\
(0.007)\end{array}$ & $\begin{array}{c}0.045^{* * *} \\
(0.007)\end{array}$ \\
\hline Log High Skill Intensive Exports & $\begin{array}{c}-0.025 \\
(0.018)\end{array}$ & $\begin{array}{l}-0.025 \\
(0.018)\end{array}$ & $\begin{array}{l}-0.025 \\
(0.018)\end{array}$ & $\begin{array}{l}-0.015 \\
(0.025)\end{array}$ & $\begin{array}{l}-0.022 \\
(0.024)\end{array}$ \\
\hline TertiaryEducation*LogHighSkillIntensiveImports & $\begin{array}{c}-0.051 * * * \\
(0.010)\end{array}$ & $\begin{array}{c}-0.050 * * * \\
(0.010)\end{array}$ & $\begin{array}{c}-0.051 * * * \\
(0.010)\end{array}$ & $\begin{array}{c}-0.053 * * * \\
(0.009)\end{array}$ & $\begin{array}{c}-0.052 * * * \\
(0.009)\end{array}$ \\
\hline Log High Skill Intensive Imports & $\begin{array}{c}0.044 \\
(0.041)\end{array}$ & $\begin{array}{c}0.046 \\
(0.040)\end{array}$ & $\begin{array}{c}0.045 \\
(0.040)\end{array}$ & $\begin{array}{c}0.028 \\
(0.047)\end{array}$ & $\begin{array}{c}0.093 * * \\
(0.044)\end{array}$ \\
\hline Tertiary Education & $\begin{array}{l}0.162 * * \\
(0.079)\end{array}$ & $\begin{array}{c}0.176^{* *} \\
(0.078)\end{array}$ & $\begin{array}{c}0.171^{* *} \\
(0.078)\end{array}$ & $\begin{array}{c}0.198 * * * \\
(0.076)\end{array}$ & $\begin{array}{c}0.191 * * \\
(0.076)\end{array}$ \\
\hline R-squared & 0.113 & 0.114 & 0.114 & 0.130 & 0.130 \\
\hline $\mathrm{N}$ & 426132 & 426132 & 426132 & 426132 & 426132 \\
\hline Country fixed effects & Yes & Yes & Yes & Yes & Yes \\
\hline Year fixed effects & Yes & Yes & Yes & Yes & Yes \\
\hline Country level characteristics & Yes & Yes & Yes & Yes & No \\
\hline Demographic characteristics & No & Yes & Yes & Yes & Yes \\
\hline Household income & No & No & Yes & Yes & No \\
\hline Country-specific linear time trends & No & No & No & Yes & Yes \\
\hline
\end{tabular}

Notes: $*$ significant at $10 \% ;{ }^{* *}$ significant at $5 \% ; * * *$ significant at $1 \%$. All specifications include multiple language and interview type dummies, though we do not report them above. Country characteristics include: Polity 2, press freedom index, the log of country population and the log of GDP per capita. Demographic characteristics include: a male dummy, age and its square, dummy variables for marital status (married/civil partnership and divorced/separated), a dummy variable for living in an urban area and presence of children in the household (any child under 15). Household income includes all wages and salaries in the household, remittances from family members living elsewhere, and all other sources before taxes. Gallup converts local income to International Dollars using the World Bank's individual consumption PPP conversion factor, which makes it comparable across all countries. Results use the Gallup sampling weights and robust standard errors are clustered at the country level. 
Table 5: OLS Estimates with High-skill Intensive Exports (Imports) and Tertiary Education Interactions

\begin{tabular}{|c|c|c|c|c|c|}
\hline & $\begin{array}{l}(1) \\
\text { OLS }\end{array}$ & $\begin{array}{l}\text { (2) } \\
\text { OLS }\end{array}$ & $\begin{array}{l}\text { (3) } \\
\text { OLS }\end{array}$ & $\begin{array}{l}4) \\
\text { OLS }\end{array}$ & $\begin{array}{l}5) \\
\text { OLS }\end{array}$ \\
\hline \multicolumn{6}{|l|}{ Outcome: Confidence in Government } \\
\hline TertiaryEducation*LogHighSkillIntensiveExports & $\begin{array}{c}0.037 * * * \\
(0.007)\end{array}$ & $\begin{array}{c}0.036^{* * *} \\
(0.007)\end{array}$ & $\begin{array}{c}0.036^{* * * *} \\
(0.007)\end{array}$ & $\begin{array}{c}0.034 * * * \\
(0.007)\end{array}$ & $\begin{array}{c}0.034 * * * \\
(0.007)\end{array}$ \\
\hline Log High Skill Intensive Exports & $\begin{array}{l}-0.010 \\
(0.015)\end{array}$ & $\begin{array}{l}-0.010 \\
(0.015)\end{array}$ & $\begin{array}{l}-0.010 \\
(0.015)\end{array}$ & $\begin{array}{c}0.007 \\
(0.021)\end{array}$ & $\begin{array}{l}-0.000 \\
(0.020)\end{array}$ \\
\hline TertiaryEducation*LogHighSkillIntensiveImports & $\begin{array}{c}-0.033 * * * \\
(0.009)\end{array}$ & $\begin{array}{c}-0.032 * * * \\
(0.009)\end{array}$ & $\begin{array}{c}-0.032 * * * \\
(0.009)\end{array}$ & $\begin{array}{c}-0.030 * * * \\
(0.009)\end{array}$ & $\begin{array}{c}-0.030 * * * \\
(0.009)\end{array}$ \\
\hline Log High Skill Intensive Imports & $\begin{array}{c}0.032 \\
(0.032)\end{array}$ & $\begin{array}{c}0.033 \\
(0.033)\end{array}$ & $\begin{array}{c}0.033 \\
(0.033)\end{array}$ & $\begin{array}{c}0.012 \\
(0.037)\end{array}$ & $\begin{array}{l}0.059^{*} \\
(0.034)\end{array}$ \\
\hline Tertiary Education & $\begin{array}{l}-0.089 \\
(0.079)\end{array}$ & $\begin{array}{l}-0.063 \\
(0.078)\end{array}$ & $\begin{array}{c}-0.062 \\
(0.078)\end{array}$ & $\begin{array}{l}-0.064 \\
(0.075)\end{array}$ & $\begin{array}{l}-0.069 \\
(0.075)\end{array}$ \\
\hline R-squared & 0.127 & 0.130 & 0.130 & 0.142 & 0.141 \\
\hline $\mathrm{N}$ & 459986 & 459986 & 459986 & 459986 & 459986 \\
\hline Country fixed effects & Yes & Yes & Yes & Yes & Yes \\
\hline Year fixed effects & Yes & Yes & Yes & Yes & Yes \\
\hline Country level characteristics & Yes & Yes & Yes & Yes & No \\
\hline Demographic characteristics & No & Yes & Yes & Yes & Yes \\
\hline Household income & No & No & Yes & Yes & No \\
\hline Country-specific linear time trends & No & No & No & Yes & Yes \\
\hline
\end{tabular}

Notes: * significant at 10\%; ${ }^{* *}$ significant at 5\%; ${ }^{* *}$ significant at 1\%. For details on control variables, see notes to Table 4. 
Table 6: IV First Stage Results for Approval of the Leader Outcome

\begin{tabular}{ccccc} 
& $(1)$ & $(2)$ & $(3)$ & $(4)$ \\
Outcome $\rightarrow$ & High-skill & High-skill & TertiaryEduc* & TertiaryEduc* \\
Intensive Exports & Intensive Imports & High-skill Intensive Exports & High-skill Intensive Imports \\
\hline
\end{tabular}

$\begin{array}{cc}\text { Predicted High-skill Intensive Exports } & 2.068^{* * *} \\ (0.556)\end{array}$

First Stage F statistics

Predicted High-skill Intensive Imports

$1.631^{* * *}$
$--\quad(0.291)$

First Stage F statistics

10.50

TertiaryEduc.*PredictedHighSkillIntensiveExports

$\begin{array}{cc} & \\ & 6.155^{* * *} \\ -- & (0.294)\end{array}$

First Stage F statistics

TertiaryEduc.*PredictedHighSkillIntensiveImports

$\begin{array}{ccc} & & \\ -- & - & \left(0.866^{* * *}\right. \\ - & - & (0.25)\end{array}$

\section{First Stage F statistics}

47.88

Observations

426132

426132

426132

426132

First Stage F Statistics for joint significance of the 26.83

26.83

26.83

26.83

Notes: $*$ significant at $10 \% ; * *$ significant at 5\%; *** significant at 1\%. For details on control variables, see notes to column 4 of Table 4 . Since the country-year coverage for the two dependent variables (approval of the leader and the confidence in government) have slightly different country-year coverage, we run the first stage regressions separately for Table 8 (for approval of the leader) and Table 9 (for confidence in government). Results use the Gallup sampling weights and robust standard errors are clustered at the country level. 
Table 7: IV First Stage Results for Confidence in Government Outcome

\begin{tabular}{lc}
\hline Outcome $\rightarrow$ & $\begin{array}{c}(1) \\
\text { High-skill } \\
\text { Intensive Export }\end{array}$ \\
\hline Predicted High-skill Intensive Exports & \\
& $2.132 * * *$ \\
& $(0.541)$
\end{tabular}

(2)

High-skill

Intensive Imports

(3)

TertiaryEduc*

High-skill Intensive Exports
(4)

TertiaryEduc*

High-skill Intensive Exports

\section{First Stage F stat}

Predicted High-skill Intensive Imports

$\begin{array}{cc} & 1.703 * * * \\ -- & (0.296)\end{array}$

\section{First Stage F stat}

14.34

TertiaryEduc.*PredictedHighSkillIntensiveExports

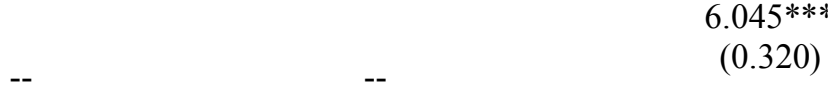

First Stage F stat

61.75

TertiaryEduc.*PredictedHighSkillIntensiveImports

$3.797 * * *$

$--$

$--$

\section{First Stage F stat}

459986

459986

459986

Observations
First Stage F Statistics for joint significance of the

459986

25.21

25.21

25.21

instruments for Column 4 of Table 9

25.21

25.21

25.21

Notes: * significant at 10\%; ** significant at 5\%; *** significant at 1\%. For details on control variables, see notes to column 4 of Table 4 . Since the country-year coverage for the two dependent variables (approval of the leader and the confidence in government) have slightly different country-year coverage, we run the first stage regressions separately for Table 8 (for approval of the leader) and Table 9 (for confidence in government). Results use the Gallup sampling weights and robust standard errors are clustered at the country level. 
Table 8: IV Estimates with High-skill Intensive Exports (Imports) and Tertiary Education Interactions

\begin{tabular}{|c|c|c|c|c|c|}
\hline & $\begin{array}{l}\text { (1) } \\
\text { IV }\end{array}$ & $\begin{array}{l}\text { (2) } \\
\text { IV }\end{array}$ & $\begin{array}{l}\text { (3) } \\
\text { IV }\end{array}$ & $\begin{array}{l}\text { (4) } \\
\text { IV }\end{array}$ & $\begin{array}{l}\text { (5) } \\
\text { IV }\end{array}$ \\
\hline \multicolumn{6}{|l|}{ Outcome: Approval of the leader } \\
\hline TertiaryEducation*LogHighSkillIntensiveExports & $\begin{array}{c}0.123 * * * \\
(0.037)\end{array}$ & $\begin{array}{c}0.119 * * * \\
(0.036)\end{array}$ & $\begin{array}{c}0.121 * * * \\
(0.036)\end{array}$ & $\begin{array}{c}0.116^{* * * *} \\
(0.035)\end{array}$ & $\begin{array}{c}0.117 * * * \\
(0.035)\end{array}$ \\
\hline Log High Skill Intensive Exports & $\begin{array}{l}-0.031 \\
(0.020)\end{array}$ & $\begin{array}{l}-0.031 \\
(0.020)\end{array}$ & $\begin{array}{l}-0.031 \\
(0.020)\end{array}$ & $\begin{array}{l}-0.021 \\
(0.031)\end{array}$ & $\begin{array}{l}-0.021 \\
(0.031)\end{array}$ \\
\hline TertiaryEducation*LogHighSkillIntensiveImports & $\begin{array}{c}-0.172 * * * \\
(0.055)\end{array}$ & $\begin{array}{c}-0.167 * * * \\
(0.053)\end{array}$ & $\begin{array}{c}-0.171 * * * \\
(0.054)\end{array}$ & $\begin{array}{c}-0.165 * * * \\
(0.052)\end{array}$ & $\begin{array}{c}-0.165 * * * \\
(0.052)\end{array}$ \\
\hline Log High Skill Intensive Imports & $\begin{array}{c}0.057 \\
(0.045)\end{array}$ & $\begin{array}{c}0.058 \\
(0.045)\end{array}$ & $\begin{array}{c}0.058 \\
(0.045)\end{array}$ & $\begin{array}{c}0.038 \\
(0.061)\end{array}$ & $\begin{array}{c}0.038 \\
(0.061)\end{array}$ \\
\hline Tertiary Education & $\begin{array}{c}1.250^{* * * *} \\
(0.475)\end{array}$ & $\begin{array}{c}1.229 * * * \\
(0.457)\end{array}$ & $\begin{array}{c}1.254 * * * \\
(0.466)\end{array}$ & $\begin{array}{c}1.218^{* * * *} \\
(0.455)\end{array}$ & $\begin{array}{c}1.218^{* * *} \\
(0.455)\end{array}$ \\
\hline KP First Stage F-Stat & 26.68 & 26.84 & 26.84 & 26.83 & 26.83 \\
\hline $\mathrm{N}$ & 426132 & 426132 & 426132 & 426132 & 426132 \\
\hline Country fixed effects & Yes & Yes & Yes & Yes & Yes \\
\hline Year fixed effects & Yes & Yes & Yes & Yes & Yes \\
\hline Country level characteristics & Yes & Yes & Yes & Yes & No \\
\hline Demographic characteristics & No & Yes & Yes & Yes & Yes \\
\hline Household income & No & No & Yes & Yes & No \\
\hline Country-specific linear time trends & No & No & No & Yes & Yes \\
\hline
\end{tabular}

Notes: ${ }^{*}$ significant at $10 \% ;{ }^{* *}$ significant at $5 \% ;{ }^{* *}$ significant at $1 \%$. For details on control variables, see notes to Table 4. 
Table 9: IV Estimates with High-skill Intensive Exports (Imports) and Tertiary Education Interaction

\begin{tabular}{|c|c|c|c|c|c|}
\hline & $\begin{array}{l}\text { (1) } \\
\text { IV }\end{array}$ & $\begin{array}{l}\text { (2) } \\
\text { IV }\end{array}$ & $\begin{array}{l}\text { (3) } \\
\text { IV }\end{array}$ & $\begin{array}{l}\text { (4) } \\
\text { IV }\end{array}$ & $\begin{array}{l}\text { (5) } \\
\text { IV }\end{array}$ \\
\hline \multicolumn{6}{|l|}{ Outcome: Confidence in Government } \\
\hline TertiaryEducation*LogHighSkillIntensiveExports & $\begin{array}{c}0.127 * * * \\
(0.042)\end{array}$ & $\begin{array}{c}0.123 * * * \\
(0.041)\end{array}$ & $\begin{array}{c}0.122 * * * \\
(0.040)\end{array}$ & $\begin{array}{c}0.113 * * * \\
(0.039)\end{array}$ & $\begin{array}{c}0.113 * * * \\
(0.039)\end{array}$ \\
\hline Log High Skill Intensive Exports & $\begin{array}{l}-0.018 \\
(0.020)\end{array}$ & $\begin{array}{l}-0.017 \\
(0.020)\end{array}$ & $\begin{array}{l}-0.017 \\
(0.020)\end{array}$ & $\begin{array}{c}0.001 \\
(0.026)\end{array}$ & $\begin{array}{l}-0.007 \\
(0.023)\end{array}$ \\
\hline TertiaryEducation*LogHighSkillIntensiveImports & $\begin{array}{c}-0.171 * * * \\
(0.062)\end{array}$ & $\begin{array}{c}-0.165^{* * *} \\
(0.060)\end{array}$ & $\begin{array}{c}-0.164 * * * \\
(0.059)\end{array}$ & $\begin{array}{c}-0.152 * * * \\
(0.058)\end{array}$ & $\begin{array}{c}-0.152 * * * \\
(0.058)\end{array}$ \\
\hline Log High Skill Intensive Imports & $\begin{array}{c}0.046 \\
(0.039)\end{array}$ & $\begin{array}{c}0.047 \\
(0.039)\end{array}$ & $\begin{array}{c}0.047 \\
(0.039)\end{array}$ & $\begin{array}{c}0.024 \\
(0.051)\end{array}$ & $\begin{array}{c}0.072 \\
(0.045)\end{array}$ \\
\hline Tertiary Education & $\begin{array}{c}1.116^{* *} \\
(0.531)\end{array}$ & $\begin{array}{c}1.096^{* *} \\
(0.508)\end{array}$ & $\begin{array}{c}1.091^{* *} \\
(0.501)\end{array}$ & $\begin{array}{c}0.999 * * \\
(0.488)\end{array}$ & $\begin{array}{l}1.002 * * \\
(0.487)\end{array}$ \\
\hline KP First Stage F-Stat & 25.06 & 25.59 & 25.22 & 25.21 & 25.21 \\
\hline $\mathrm{N}$ & 459986 & 459986 & 459986 & 459986 & 459986 \\
\hline Country fixed effects & Yes & Yes & Yes & Yes & Yes \\
\hline Year fixed effects & Yes & Yes & Yes & Yes & Yes \\
\hline Country level characteristics & Yes & Yes & Yes & Yes & No \\
\hline Demographic characteristics & No & Yes & Yes & Yes & Yes \\
\hline Household income & No & No & Yes & Yes & No \\
\hline Country-specific linear time trends & No & No & No & Yes & Yes \\
\hline
\end{tabular}

Notes: * significant at 10\%; ** significant at 5\%; *** significant at 1\%. For details on control variables, see notes to Table 4. 
Table 10: Predicted and Actual Effects

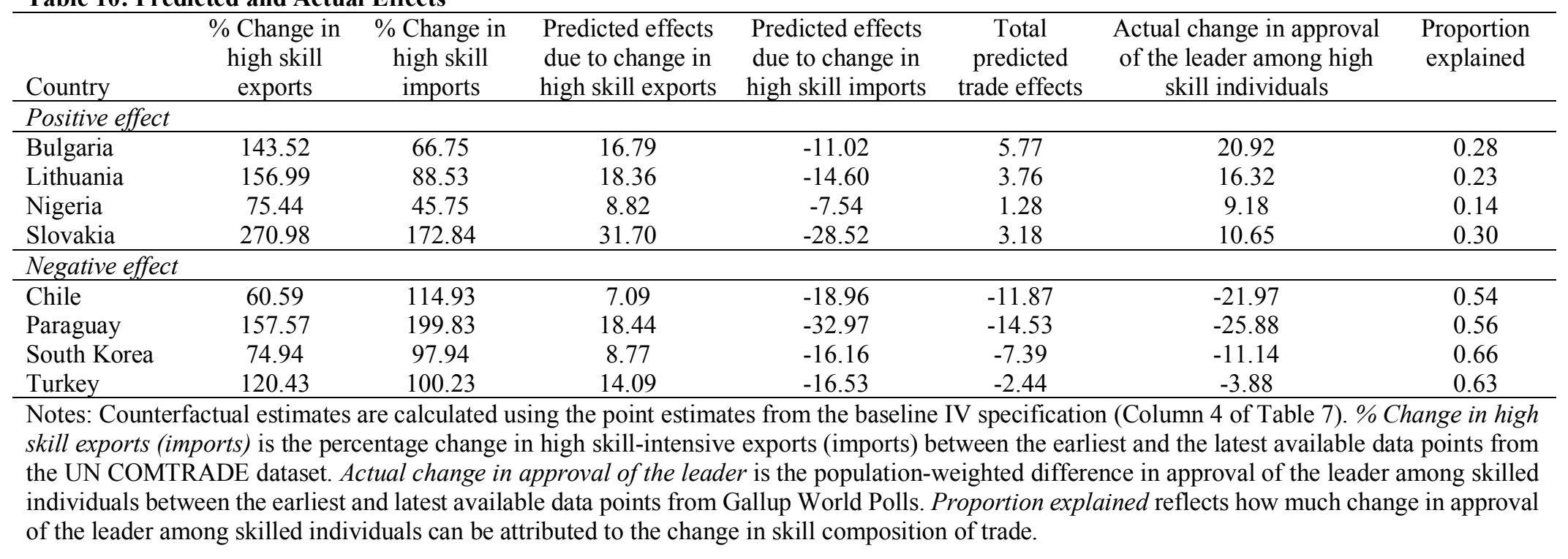


Table 11: IV Estimates - Sub-sample Analysis by Gender and Age

\begin{tabular}{lcccc}
\hline & $(1)$ & $(2)$ & $(3)$ & $(4)$ \\
& IV & IV & IV & IV \\
& Male & Female & $25-44$ & $45-64$ \\
\hline Outcome: Approval of the leader & & & & \\
TertiaryEducation*LogHighSkillIntensiveExports & $0.121^{* * *}$ & $0.108^{* * *}$ & $0.125^{* * *}$ & $0.108^{* * *}$ \\
& $(0.025)$ & $(0.024)$ & $(0.025)$ & $(0.026)$ \\
Log High Skill Intensive Exports & -0.014 & -0.027 & -0.013 & -0.038 \\
& $(0.027)$ & $(0.024)$ & $(0.025)$ & $(0.026)$ \\
TertiaryEducation*LogHighSkillIntensiveImports & $-0.171^{* * *}$ & $-0.153^{* * *}$ & $-0.178^{* * *}$ & $-0.150^{* * *}$ \\
& $(0.037)$ & $(0.036)$ & $(0.037)$ & $(0.038)$ \\
Log High Skill Intensive Imports & 0.040 & 0.036 & 0.045 & 0.034 \\
& $(0.049)$ & $(0.048)$ & $(0.048)$ & $(0.049)$ \\
Tertiary Education & $1.276^{* * *}$ & $1.124 * * *$ & $1.343^{* * *}$ & $1.070^{* * *}$ \\
& $(0.305)$ & $(0.312)$ & $(0.318)$ & $(0.303)$ \\
N & & & 242572 & 183560 \\
\hline Outcome: Confidence in Government & 193590 & 232542 & & \\
TertiaryEducation*LogHighSkillIntensiveExports & $0.107^{* * *}$ & $0.116^{* * *}$ & $0.117^{* * *}$ & $0.118^{* * *}$ \\
& $(0.024)$ & $(0.026)$ & $(0.025)$ & $(0.027)$ \\
Log High Skill Intensive Exports & -0.004 & 0.005 & 0.001 & 0.001 \\
TertiaryEducation*LogHighSkillIntensiveImports & $(0.023)$ & $(0.020)$ & $(0.021)$ & $(0.023)$ \\
Log High Skill Intensive Imports & $-0.141^{* * *}$ & $-0.159^{* * *}$ & $-0.159^{* * *}$ & $-0.156^{* * *}$ \\
Tertiary Education & $(0.036)$ & $(0.040)$ & $(0.038)$ & $(0.038)$ \\
N & 0.011 & 0.037 & 0.033 & 0.009 \\
\hline No & $(0.039)$ & $(0.038)$ & $(0.037)$ & $(0.040)$ \\
& $0.884^{* * *}$ & $1.106^{* * *}$ & $1.079^{* * *}$ & $0.987 * * *$ \\
\end{tabular}

Notes: * significant at 10\%; ** significant at 5\%; *** significant at 1\%. For details on control variables, see notes to column 4 of Table 4. 
Table 12: IV Estimates - Sub-sample Analysis by Urbanity Status and Household Income

\begin{tabular}{|c|c|c|c|c|c|}
\hline & $\begin{array}{c}\text { (1) } \\
\text { IV } \\
\text { Urban }\end{array}$ & $\begin{array}{c}\text { (2) } \\
\text { IV } \\
\text { Rural }\end{array}$ & $\begin{array}{c}\text { (3) } \\
\text { IV } \\
\text { Low-income HH } \\
\text { (bottom tercile) }\end{array}$ & $\begin{array}{c}\text { (4) } \\
\text { IV } \\
\text { Middle-income HH } \\
\text { (middle tercile) }\end{array}$ & $\begin{array}{c}\text { (5) } \\
\text { IV } \\
\text { High-income HH } \\
\text { (top tercile) }\end{array}$ \\
\hline \multicolumn{6}{|l|}{ Outcome: Approval of the leader } \\
\hline TertiaryEducation*LogHighSkillIntensiveExports & $\begin{array}{c}0.097 * * * \\
(0.023)\end{array}$ & $\begin{array}{c}0.164 * * * \\
(0.031)\end{array}$ & $\begin{array}{l}0.127^{*} \\
(0.068)\end{array}$ & $\begin{array}{c}0.123 * * * \\
(0.031)\end{array}$ & $\begin{array}{c}0.038 * * \\
(0.018)\end{array}$ \\
\hline Log High Skill Intensive Exports & $\begin{array}{l}-0.033 \\
(0.034)\end{array}$ & $\begin{array}{l}-0.018 \\
(0.025)\end{array}$ & $\begin{array}{l}-0.002 \\
(0.026)\end{array}$ & $\begin{array}{l}-0.025 \\
(0.031)\end{array}$ & $\begin{array}{c}0.013 \\
(0.048)\end{array}$ \\
\hline TertiaryEducation*LogHighSkillIntensiveImports & $\begin{array}{c}-0.144 * * * \\
(0.034)\end{array}$ & $\begin{array}{c}-0.228^{* * *} \\
(0.046)\end{array}$ & $\begin{array}{c}-0.186^{*} \\
(0.101)\end{array}$ & $\begin{array}{c}-0.184^{* * *} \\
(0.048)\end{array}$ & $\begin{array}{c}-0.059 * * \\
(0.026)\end{array}$ \\
\hline Log High Skill Intensive Imports & $\begin{array}{c}0.063 \\
(0.061)\end{array}$ & $\begin{array}{c}0.028 \\
(0.047)\end{array}$ & $\begin{array}{c}0.056 \\
(0.056)\end{array}$ & $\begin{array}{c}0.064 \\
(0.052)\end{array}$ & $\begin{array}{l}-0.044 \\
(0.075)\end{array}$ \\
\hline Tertiary Education & $\begin{array}{c}1.179 * * * \\
(0.300)\end{array}$ & $\begin{array}{c}1.631^{* * * *} \\
(0.383)\end{array}$ & $\begin{array}{l}1.414^{*} \\
(0.831)\end{array}$ & $\begin{array}{c}1.509 * * * \\
(0.430)\end{array}$ & $\begin{array}{c}0.523 * * \\
(0.234)\end{array}$ \\
\hline $\mathrm{N}$ & 183335 & 242797 & 120404 & 138273 & 155550 \\
\hline \multicolumn{6}{|l|}{ Outcome: Confidence in Government } \\
\hline TertiaryEducation*LogHighSkillIntensiveExports & $\begin{array}{c}0.085 * * * \\
(0.022)\end{array}$ & $\begin{array}{c}0.173 * * * \\
(0.035)\end{array}$ & $\begin{array}{c}0.173 * * \\
(0.084)\end{array}$ & $\begin{array}{c}0.102 * * * \\
(0.028)\end{array}$ & $\begin{array}{c}0.050 * * * \\
(0.019)\end{array}$ \\
\hline Log High Skill Intensive Exports & $\begin{array}{c}0.018 \\
(0.026)\end{array}$ & $\begin{array}{l}-0.007 \\
(0.022)\end{array}$ & $\begin{array}{c}0.002 \\
(0.024)\end{array}$ & $\begin{array}{c}0.017 \\
(0.023)\end{array}$ & $\begin{array}{c}0.031 \\
(0.045)\end{array}$ \\
\hline TertiaryEducation*LogHighSkillIntensiveImports & $\begin{array}{c}-0.115^{* * *} \\
(0.032)\end{array}$ & $\begin{array}{c}-0.238^{* * *} \\
(0.051)\end{array}$ & $\begin{array}{c}-0.258^{* *} \\
(0.125)\end{array}$ & $\begin{array}{c}-0.150^{* * *} \\
(0.044)\end{array}$ & $\begin{array}{c}-0.063 * * \\
(0.027)\end{array}$ \\
\hline Log High Skill Intensive Imports & $\begin{array}{c}0.006 \\
(0.043)\end{array}$ & $\begin{array}{c}0.033 \\
(0.039)\end{array}$ & $\begin{array}{l}0.072 * \\
(0.044)\end{array}$ & $\begin{array}{c}0.009 \\
(0.041)\end{array}$ & $\begin{array}{l}-0.082 \\
(0.060)\end{array}$ \\
\hline Tertiary Education & $\begin{array}{c}0.778 * * * \\
(0.285)\end{array}$ & $\begin{array}{c}1.647 * * * \\
(0.423)\end{array}$ & $\begin{array}{c}2.053 * * \\
(1.039)\end{array}$ & $\begin{array}{c}1.160 * * * \\
(0.407)\end{array}$ & $\begin{array}{c}0.367 \\
(0.242)\end{array}$ \\
\hline $\mathrm{N}$ & 197817 & 262169 & 125191 & 144288 & 170936 \\
\hline
\end{tabular}

Notes: * significant at 10\%; ** significant at 5\%; *** significant at 1\%. For details on control variables, see notes to column 4 of Table 4. 
Table 13: IV Estimates - Sub-sample Analysis by Country Income Levels and Political Regime by Country

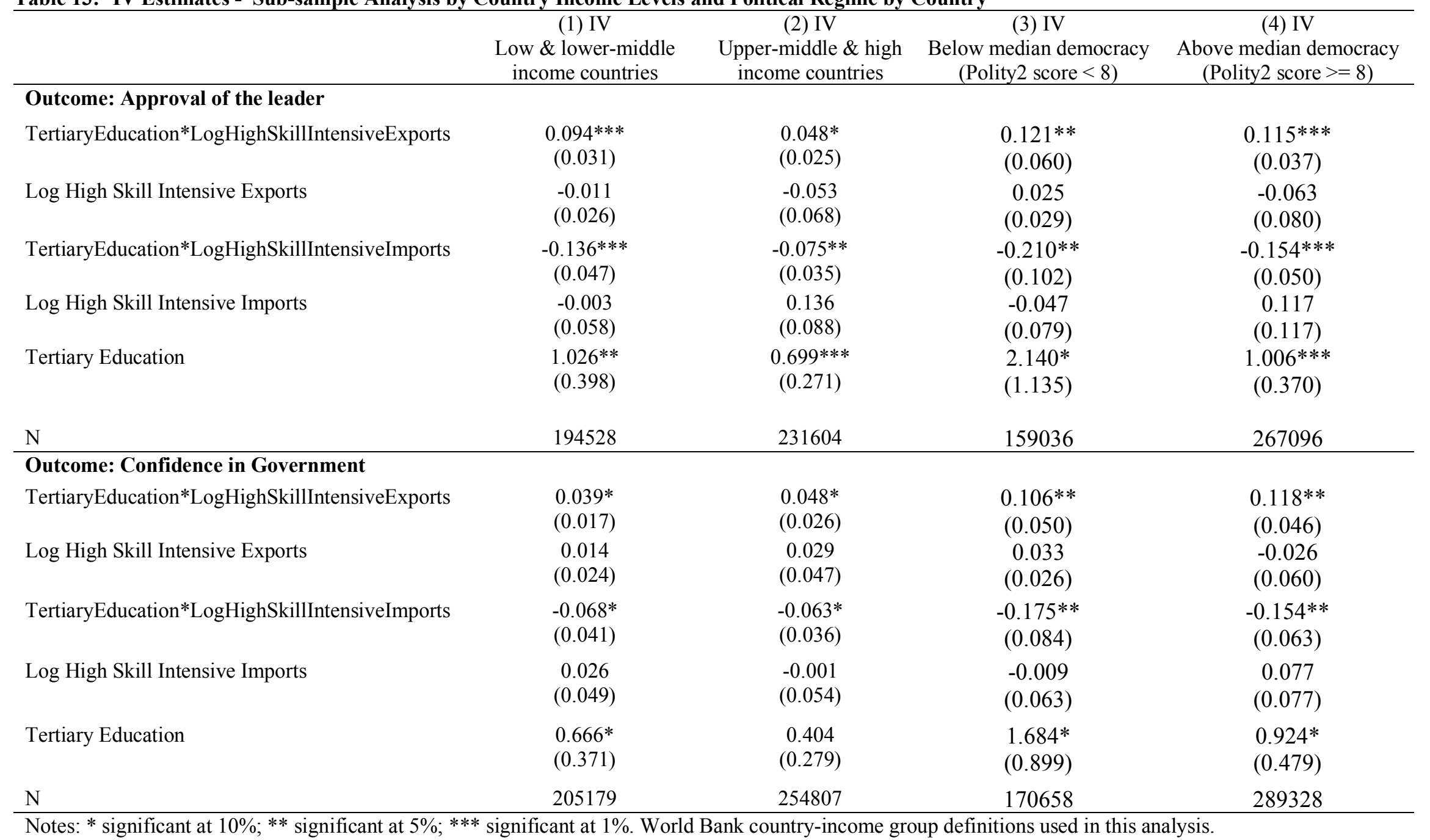


Table 14: IV Estimates - Placebo Outcomes

\begin{tabular}{|c|c|c|c|}
\hline & $\begin{array}{l}(1) \\
\text { IV }\end{array}$ & & $\begin{array}{l}\text { (2) } \\
\text { IV }\end{array}$ \\
\hline Outcome: Confidence in the military & & Outcome: Confidence in the judicial system & \\
\hline TertiaryEducation*LogHighSkillIntensiveExports & $\begin{array}{c}-0.000 \\
(0.097)\end{array}$ & TertiaryEducation* LogHighSkillIntensiveExports & $\begin{array}{c}0.099 \\
(0.128)\end{array}$ \\
\hline Log High Skill Intensive Exports & $\begin{array}{l}-0.009 \\
(0.013)\end{array}$ & Log High Skill Intensive Exports & $\begin{array}{l}-0.015 \\
(0.017)\end{array}$ \\
\hline TertiaryEducation*LogHighSkillIntensiveImports & $\begin{array}{c}0.007 \\
(0.133)\end{array}$ & TertiaryEducation*LogHighSkillIntensiveImports & $\begin{array}{l}-0.097 \\
(0.176)\end{array}$ \\
\hline Log High Skill Intensive Imports & $\begin{array}{c}0.002 \\
(0.026)\end{array}$ & Log High Skill Intensive Imports & $\begin{array}{l}0.053 * \\
(0.029)\end{array}$ \\
\hline Tertiary Education & $\begin{array}{l}-0.180 \\
(0.899)\end{array}$ & Tertiary Education & $\begin{array}{c}0.017 \\
(0.214)\end{array}$ \\
\hline $\mathrm{N}$ & 408206 & $\mathrm{~N}$ & 413780 \\
\hline Outcome: Confidence in honesty of elections & & Outcome: Confidence in media (freedom) & \\
\hline TertiaryEducation*LogHighSkillIntensiveExports & $\begin{array}{c}0.336 \\
(0.263)\end{array}$ & TertiaryEducation*LogHighSkillIntensiveExports & $\begin{array}{c}0.155 \\
(0.228)\end{array}$ \\
\hline Log High Skill Intensive Exports & $\begin{array}{c}-0.027 \\
(0.022)\end{array}$ & Log High Skill Intensive Exports & $\begin{array}{c}0.021 \\
(0.033)\end{array}$ \\
\hline TertiaryEducation*LogHighSkillIntensiveImports & $\begin{array}{l}-0.420 \\
(0.365)\end{array}$ & TertiaryEducation*LogHighSkillIntensiveImports & $\begin{array}{c}-0.202 \\
(0.309)\end{array}$ \\
\hline Log High Skill Intensive Imports & $\begin{array}{c}0.096 \\
(0.086)\end{array}$ & Log High Skill Intensive Imports & $\begin{array}{l}-0.060 \\
(0.055)\end{array}$ \\
\hline Tertiary Education & $\begin{array}{c}-0.695 \\
(1.155)\end{array}$ & Tertiary Education & $\begin{array}{c}1.154 \\
(2.046)\end{array}$ \\
\hline $\mathrm{N}$ & 415654 & $\mathrm{~N}$ & 179432 \\
\hline
\end{tabular}


Table 15: IV Estimates - Robustness

(1) (2)

(2)

Outcome is $\rightarrow$ Approval of the leader Confidence in government

Controls for individual unemployment

TertiaryEducation*LogHighSkillIntensiveExports

$0.119^{* * *}$

$0.132 * * *$

$(0.024)$

$(0.026)$

Log High Skill Intensive Exports

$-0.008$

$-0.002$

$(0.027)$

TertiaryEducation*LogHighSkillIntensiveImports

$-0.169^{* * *}$

$-0.180^{* * *}$

$(0.035)$

(0.039)

Log High Skill Intensive Imports

$-0.117 * *$

$-0.064$

$(0.048)$

Tertiary Education

$1.251 * * *$

$1.214 * * *$

$(0.301)$

$(0.336)$

Unemployed

$-0.048 * * *$

$-0.041 * * *$

$(0.005)$

$\mathrm{N}$

348306

371620

Excluding election years

TertiaryEducation*LogHighSkillIntensiveExports

$0.130 * * *$

$0.120 * * *$

Log High Skill Intensive Exports

$-0.031$

0.005

$(0.040)$

TertiaryEducation*LogHighSkillIntensiveImports

$-0.188^{* * *}$

$-0.167 * *$

$(0.058)$

$(0.069)$

Log High Skill Intensive Imports

0.054

0.019

$(0.065)$

$(0.055)$

Tertiary Education

$1.451 * * *$

$1.189^{* *}$

$(0.505)$

$(0.603)$

$\mathrm{N}$

302148

324805

Notes: * significant at $10 \%$; * significant at $5 \%$; ** significant at $1 \%$. For details on control variables, see notes to Column 4 of Table 4 . A respondent is defined as unemployed if he/she reports not being employed in the last seven days, either for an employer or for himself or herself. The respondent must also report actively looking for a job in the past four weeks and being able to begin work in the last four weeks. Election years refer to having a parliamentary or presidential election in a given calendar year. 
Table 16: IV Estimates - Robustness

\begin{tabular}{|c|c|c|}
\hline Outcome is $\rightarrow$ & $\begin{array}{c}\text { (1) } \\
\text { IV } \\
\text { Approval of the leader }\end{array}$ & $\begin{array}{c}\text { (2) } \\
\text { IV } \\
\text { Confidence in Government }\end{array}$ \\
\hline \multicolumn{3}{|l|}{ Controls for leaders' continuous tenure } \\
\hline TertiaryEducation*LogHighSkillIntensiveExports & $\begin{array}{c}0.114 * * * \\
(0.023)\end{array}$ & $\begin{array}{c}0.109 * * * \\
(0.023)\end{array}$ \\
\hline Log High Skill Intensive Exports & $\begin{array}{l}-0.013 \\
(0.024)\end{array}$ & $\begin{array}{c}0.005 \\
(0.021)\end{array}$ \\
\hline TertiaryEducation*LogHighSkillIntensiveImports & $\begin{array}{c}-0.161 * * * \\
(0.034)\end{array}$ & $\begin{array}{c}-0.147 * * * \\
(0.034)\end{array}$ \\
\hline Log High Skill Intensive Imports & $\begin{array}{c}0.048 \\
(0.046)\end{array}$ & $\begin{array}{c}0.032 \\
(0.035)\end{array}$ \\
\hline Tertiary Education & $\begin{array}{c}1.190 * * * \\
(0.294)\end{array}$ & $\begin{array}{c}0.960 * * * \\
(0.293)\end{array}$ \\
\hline $\mathrm{N}$ & 416121 & 452476 \\
\hline \multicolumn{3}{|l|}{ Lowering minimum age in the sample to 15} \\
\hline TertiaryEducation*LogHighSkillIntensiveExports & $\begin{array}{c}0.109 * * * \\
(0.021)\end{array}$ & $\begin{array}{c}0.116^{* * * *} \\
(0.022)\end{array}$ \\
\hline Log High Skill Intensive Exports & $\begin{array}{l}-0.014 \\
(0.024)\end{array}$ & $\begin{array}{c}0.000 \\
(0.021)\end{array}$ \\
\hline TertiaryEducation*LogHighSkillIntensiveImports & $\begin{array}{c}-0.157 * * * \\
(0.032)\end{array}$ & $\begin{array}{c}-0.161 * * * \\
(0.034)\end{array}$ \\
\hline Log High Skill Intensive Imports & $\begin{array}{c}0.044 \\
(0.046)\end{array}$ & $\begin{array}{c}0.038 \\
(0.035)\end{array}$ \\
\hline Tertiary Education & $\begin{array}{c}1.199 * * * \\
(0.272)\end{array}$ & $\begin{array}{c}1.130 * * * \\
(0.288)\end{array}$ \\
\hline $\mathrm{N}$ & 545361 & 586075 \\
\hline
\end{tabular}

Notes: * significant at $10 \% ;{ }^{* *}$ significant at $5 \% ; * * *$ significant at $1 \%$. For details on control variables, see notes to Column 4 of Table 4. 
Table 17: IV Estimates for Outsourcing Destination Countries

\begin{tabular}{|c|c|c|c|}
\hline Sample is $\rightarrow$ & $\begin{array}{c}(1) \\
\text { IV } \\
\text { Outsourcing } \\
\text { destination } \\
\text { countries }\end{array}$ & $\begin{array}{c}\text { (2) } \\
\text { IV } \\
\text { Non-outsourcing } \\
\text { developing } \\
\text { countries }\end{array}$ & $\begin{array}{c}\text { (3) } \\
\text { IV } \\
\text { Other upper- } \\
\text { middle or high } \\
\text { income countries }\end{array}$ \\
\hline \multicolumn{4}{|l|}{ Outcome: Approval of the leader } \\
\hline TertiaryEducation*LogHighSkillIntensviveExports & $\begin{array}{l}-0.496 \\
(1.055)\end{array}$ & $\begin{array}{l}0.219 * \\
(0.120)\end{array}$ & $\begin{array}{c}0.050 * * * \\
(0.017)\end{array}$ \\
\hline Log High Skill Intensive Exports & $\begin{array}{c}-0.213^{* *} \\
(0.098)\end{array}$ & $\begin{array}{c}0.010 \\
(0.024)\end{array}$ & $\begin{array}{c}0.059 \\
(0.052)\end{array}$ \\
\hline TertiaryEducation*LogHighSkillIntensiveImports & $\begin{array}{c}1.242 \\
(2.551)\end{array}$ & $\begin{array}{c}-0.292 * \\
(0.173)\end{array}$ & $\begin{array}{c}-0.066^{* * *} \\
(0.023)\end{array}$ \\
\hline Log High Skill Intensive Imports & $\begin{array}{l}-0.111 \\
(0.279)\end{array}$ & $\begin{array}{l}-0.102 \\
(0.069)\end{array}$ & $\begin{array}{l}-0.017 \\
(0.079)\end{array}$ \\
\hline Tertiary Education & $\begin{array}{l}-18.00 \\
(36.20)\end{array}$ & $\begin{array}{c}1.862 \\
(1.335)\end{array}$ & $\begin{array}{c}0.422 * * \\
(0.173)\end{array}$ \\
\hline $\mathrm{N}$ & 160669 & 94247 & 171216 \\
\hline \multicolumn{4}{|l|}{ Outcome: Confidence in Government } \\
\hline TertiaryEducation*LogHighSkillIntensiveExports & $\begin{array}{l}-0.543 \\
(1.710)\end{array}$ & $\begin{array}{c}0.262 * * \\
(0.118)\end{array}$ & $\begin{array}{l}0.031 * \\
(0.017)\end{array}$ \\
\hline Log High Skill Intensive Exports & $\begin{array}{l}-0.103 \\
(0.101)\end{array}$ & $\begin{array}{c}0.003 \\
(0.022)\end{array}$ & $\begin{array}{c}0.100 * * * \\
(0.044)\end{array}$ \\
\hline TertiaryEducation*LogHighSkillIntensiveImports & $\begin{array}{c}1.327 \\
(4.150)\end{array}$ & $\begin{array}{c}-0.349 * * \\
(0.172)\end{array}$ & $\begin{array}{l}-0.030 \\
(0.023)\end{array}$ \\
\hline Log High Skill Intensive Imports & $\begin{array}{l}-0.150 \\
(0.409)\end{array}$ & $\begin{array}{c}0.022 \\
(0.060)\end{array}$ & $\begin{array}{l}-0.102 \\
(0.064)\end{array}$ \\
\hline Tertiary Education & $\begin{array}{l}-18.942 \\
(58.975)\end{array}$ & $\begin{array}{l}2.229 * \\
(1.344)\end{array}$ & $\begin{array}{c}0.022 \\
(0.177)\end{array}$ \\
\hline $\mathrm{N}$ & 176001 & 97619 & 186366 \\
\hline
\end{tabular}

Notes: $*$ significant at $10 \% ; * *$ significant at $5 \% ; * * *$ significant at $1 \%$. For details on control variables, see notes to Column 4 of Table 4. Outsourcing destination countries (35) are as follows (based on A.T. Kearney Global Services Location Index): Argentina, Bangladesh, Brazil, Bulgaria, Chile, China, Colombia, Costa Rica, Czech Republic, Egypt, Estonia, Ghana, Hungary, India, Indonesia, Kenya, Latvia, Lithuania, Malaysia, Mauritius, Mexico, Morocco, Pakistan, Peru, Philippines, Poland, Portugal, Romania, Russia, Sri Lanka, Ukraine, Thailand, Tunisia, Turkey, Vietnam. 
Table 18: Estimates for Individual Economic Outcomes

\begin{tabular}{|c|c|c|c|c|}
\hline Outcome $\rightarrow$ & $\begin{array}{c}\text { (1) } \\
\text { OLS } \\
\text { Unemployed } \\
\end{array}$ & $\begin{array}{c}\text { (2) } \\
\text { IV } \\
\text { Unemployed } \\
\end{array}$ & $\begin{array}{c}\text { (3) } \\
\text { OLS } \\
\text { (ln) Income }\end{array}$ & $\begin{array}{c}\text { (4) } \\
\text { IV } \\
\text { (ln) Income } \\
\end{array}$ \\
\hline TertiaryEducation*LogHighSkillIntensiveExports & $\begin{array}{c}-0.007 * * * \\
(0.002)\end{array}$ & $\begin{array}{c}-0.007 \\
(0.012)\end{array}$ & $\begin{array}{c}0.090 * * * \\
(0.019)\end{array}$ & $\begin{array}{c}0.587 * * * \\
(0.205)\end{array}$ \\
\hline Share of high skill intensive exports & $\begin{array}{c}0.008 \\
(0.006)\end{array}$ & $\begin{array}{c}0.007 \\
(0.008)\end{array}$ & $\begin{array}{c}0.028 \\
(0.037)\end{array}$ & $\begin{array}{c}0.069 \\
(0.047)\end{array}$ \\
\hline TertiaryEducation*LogHighSkillIntensiveImports & $\begin{array}{c}0.011 * * * \\
(0.003)\end{array}$ & $\begin{array}{c}0.009 \\
(0.018)\end{array}$ & $\begin{array}{c}-0.065^{* * *} \\
(0.025)\end{array}$ & $\begin{array}{c}-0.842 * * * \\
(0.318)\end{array}$ \\
\hline Share of high skill intensive imports & $\begin{array}{c}0.013 \\
(0.012)\end{array}$ & $\begin{array}{c}0.015 \\
(0.018)\end{array}$ & $\begin{array}{c}0.079 \\
(0.086)\end{array}$ & $\begin{array}{c}0.010 \\
(0.122)\end{array}$ \\
\hline Tertiary Education & $\begin{array}{c}-0.122^{* * *} \\
(0.033)\end{array}$ & $\begin{array}{l}-0.038 \\
(0.148)\end{array}$ & $\begin{array}{c}1.037 * * * \\
(0.197)\end{array}$ & $\begin{array}{l}5.910 * * \\
(2.916)\end{array}$ \\
\hline $\mathrm{N}$ & 323486 & 323486 & 397036 & 397036 \\
\hline Country fixed effects & Yes & Yes & Yes & Yes \\
\hline Year fixed effects & Yes & Yes & Yes & Yes \\
\hline Country-specific linear time trends & Yes & Yes & Yes & Yes \\
\hline Demographic characteristics & Yes & Yes & Yes & Yes \\
\hline Country-level characteristics & Yes & Yes & Yes & Yes \\
\hline
\end{tabular}


Table 19: IV Estimates - Controlling for Average Tariff Rates

\begin{tabular}{lcc}
\hline & $(1)$ & $(2)$ \\
\hline Outcome is $\rightarrow$ & IV & Confidence in government \\
\hline & & \\
TertiaryEducation*LogHighSkillIntensiveExports & $0.117 * * *$ & $(0.039)$ \\
& $(0.037)$ & 0.003 \\
Log High Skill Intensive Exports & -0.016 & $(0.026)$ \\
& $(0.032)$ & $-0.144 * * *$ \\
TertiaryEducation*LogHighSkillIntensiveImports & $-0.164 * * *$ & $(0.057)$ \\
& $(0.056)$ & 0.015 \\
Log High Skill Intensive Imports & 0.047 & $(0.046)$ \\
Tertiary Education & $(0.068)$ & $0.911 *$ \\
Log Tariff Rate (simple mean) & $1.198 * * *$ & $(0.476)$ \\
& $(0.485)$ & 0.027 \\
N & 0.052 & $(0.023)$ \\
Notes: $*$ significant at 10\%; $* *$ significant at 5\%; $* * *$ significant at $1 \%$ For details on control variables, see
\end{tabular}


Table 20: IV Estimates with High-skill Trade and Secondary and Tertiary Education Interactions

(1)

IV

IV Approval of the leader Confidence in Government

SecondaryEducation*LogHighSkillIntensiveExports

$0.109^{*}$

(0.063)

TertiaryEducation*LogHighSkillIntensiveExports

SecondaryEducation*LogHighSkillIntensiveImports

TertiaryEducation*LogHighSkillIntensiveImports

Log High Skill Intensive Exports

Log High Skill Intensive Imports

Tertiary Education

Secondary Education

1.424

$\begin{array}{cc}0.193^{* * *} & 0.210^{* *} \\ (0.070) & (0.094) \\ -0.167^{*} & -0.219 \\ (0.099) & (0.142) \\ -0.284^{* * *} & -0.306^{* *} \\ (0.109) & (0.148) \\ -0.063^{*} & -0.049 \\ (0.036) & (0.043)\end{array}$

0.074

(0.068)

0.092

(0.073)

$2.231 * *$

(0.988)

$2.357 *$

(1.364)

$(0.905)$

406655
1.897

(1.319) 436916

$\mathrm{N}$

Notes: $*$ significant at $10 \% ; * *$ significant at $5 \% ; * * *$ significant at $1 \%$. For details on control variables, see notes to Coll 4 of Table 4. 
Appendix Figure 1: Low-skill Intensive Exports vs. Predicted Low-skill Intensive Exports

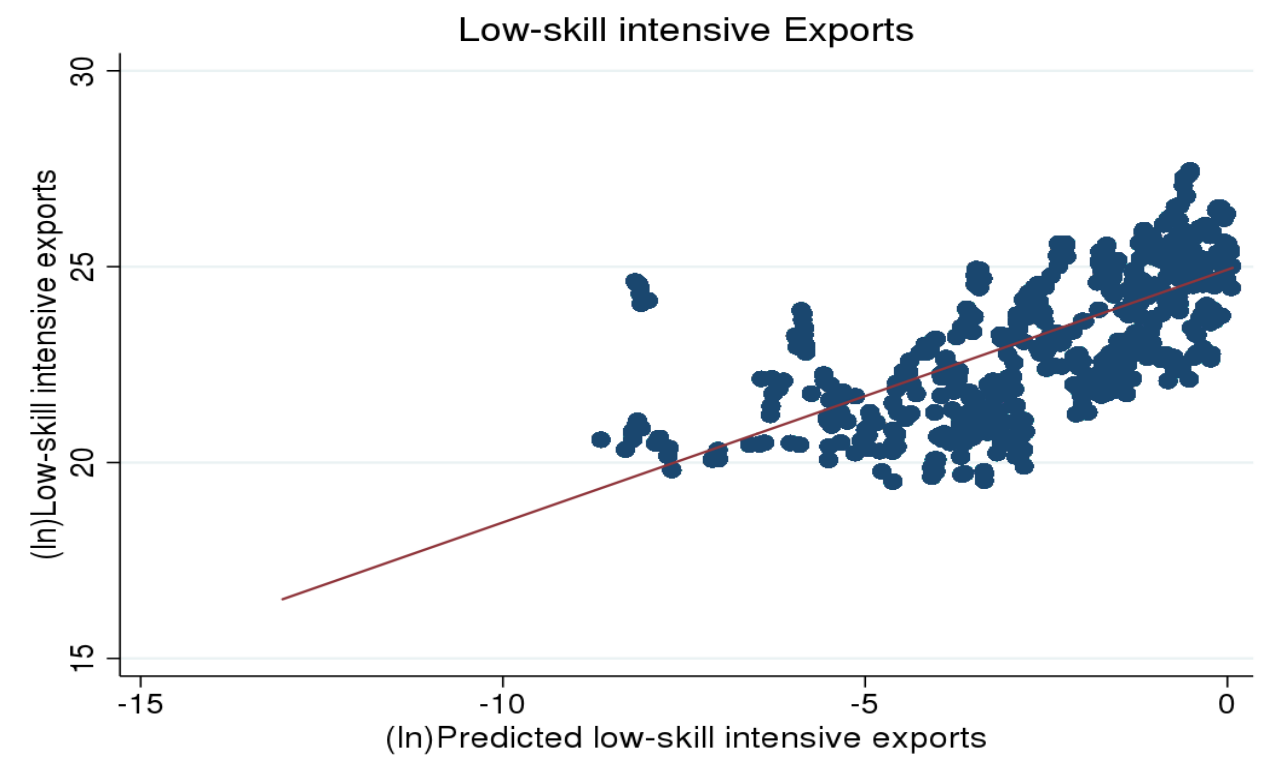

Notes: The graph plots actual low-skill intensive exports against predicted low-skill intensive exports following the IV strategy introduced in Section 4.2.

Appendix Figure 2: Low-skill Intensive Imports vs. Predicted Low-skill Intensive Imports

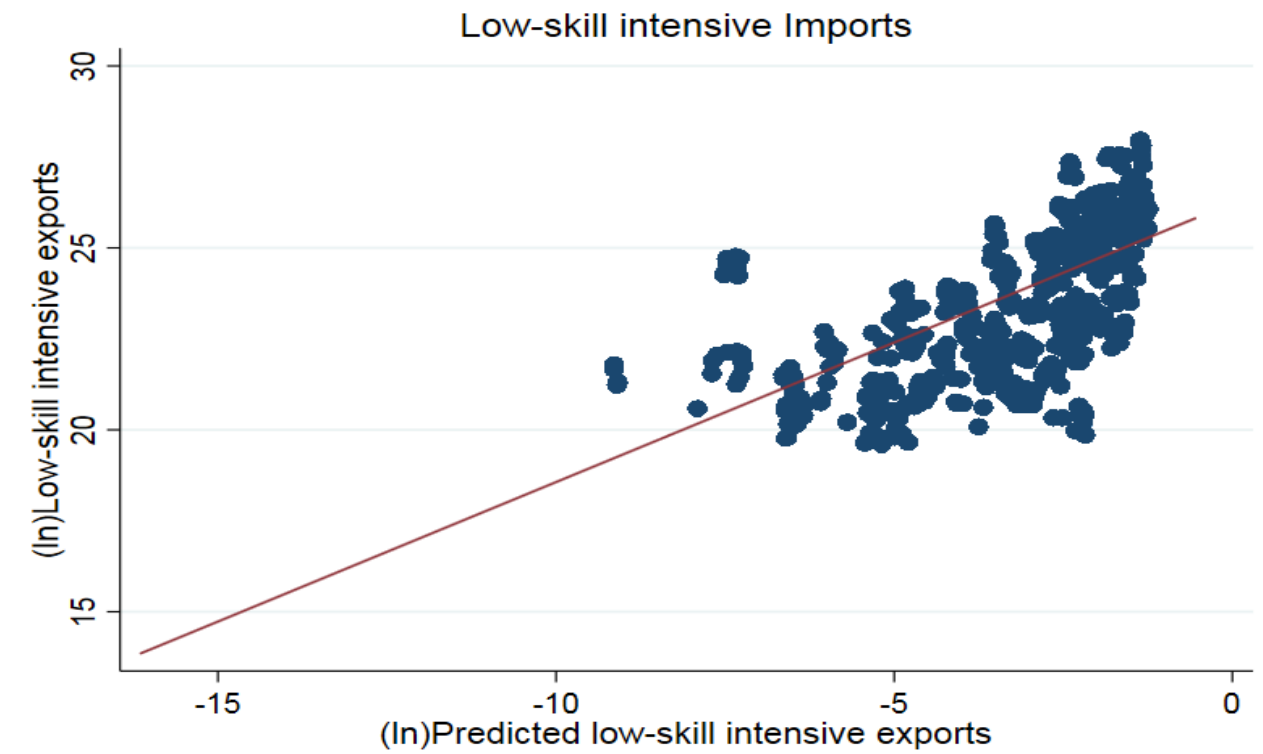

Notes: The graph plots actual low-skill intensive imports against predicted low-skill intensive imports following the IV strategy introduced in Section 4.2. 
Appendix Figure 3: Average Tariff Rates, 2005-2015

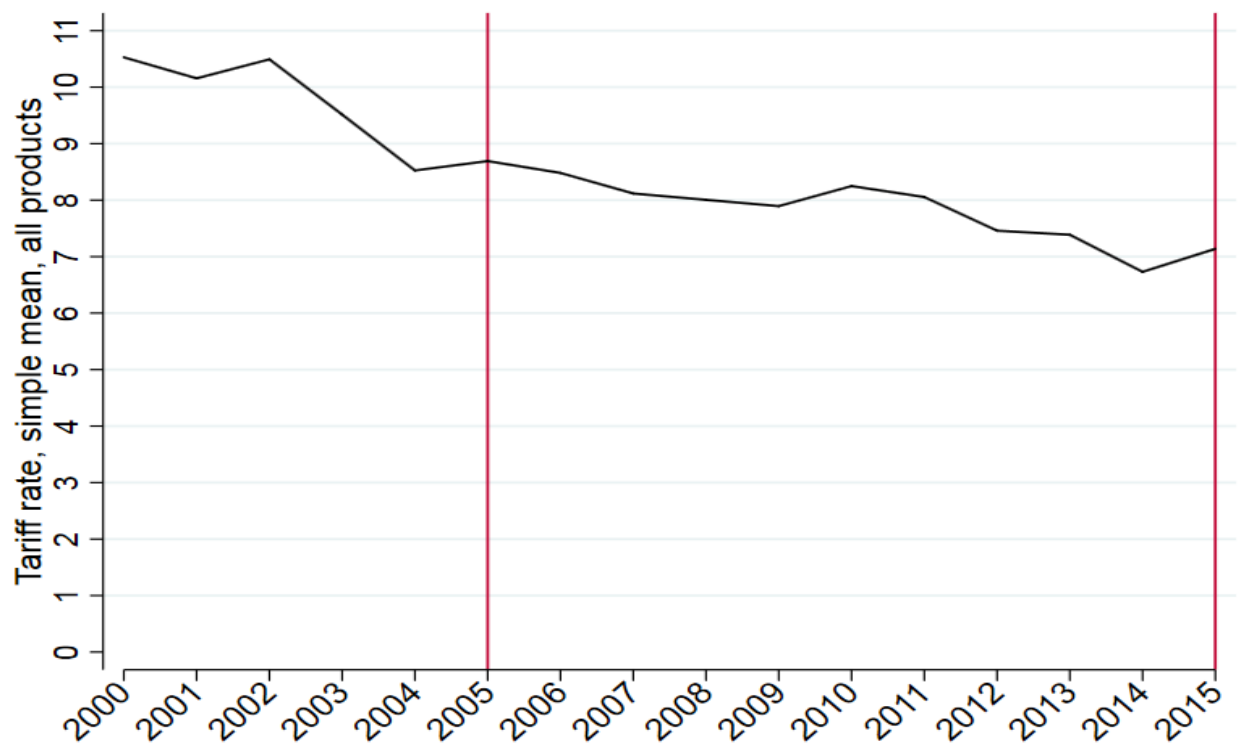

Source: World Development Indicators. 
Appendix Table 1: Expanded Set of Coefficients, Fully Saturated Model (i.e. Column 4 of Tables 7 and 8 )

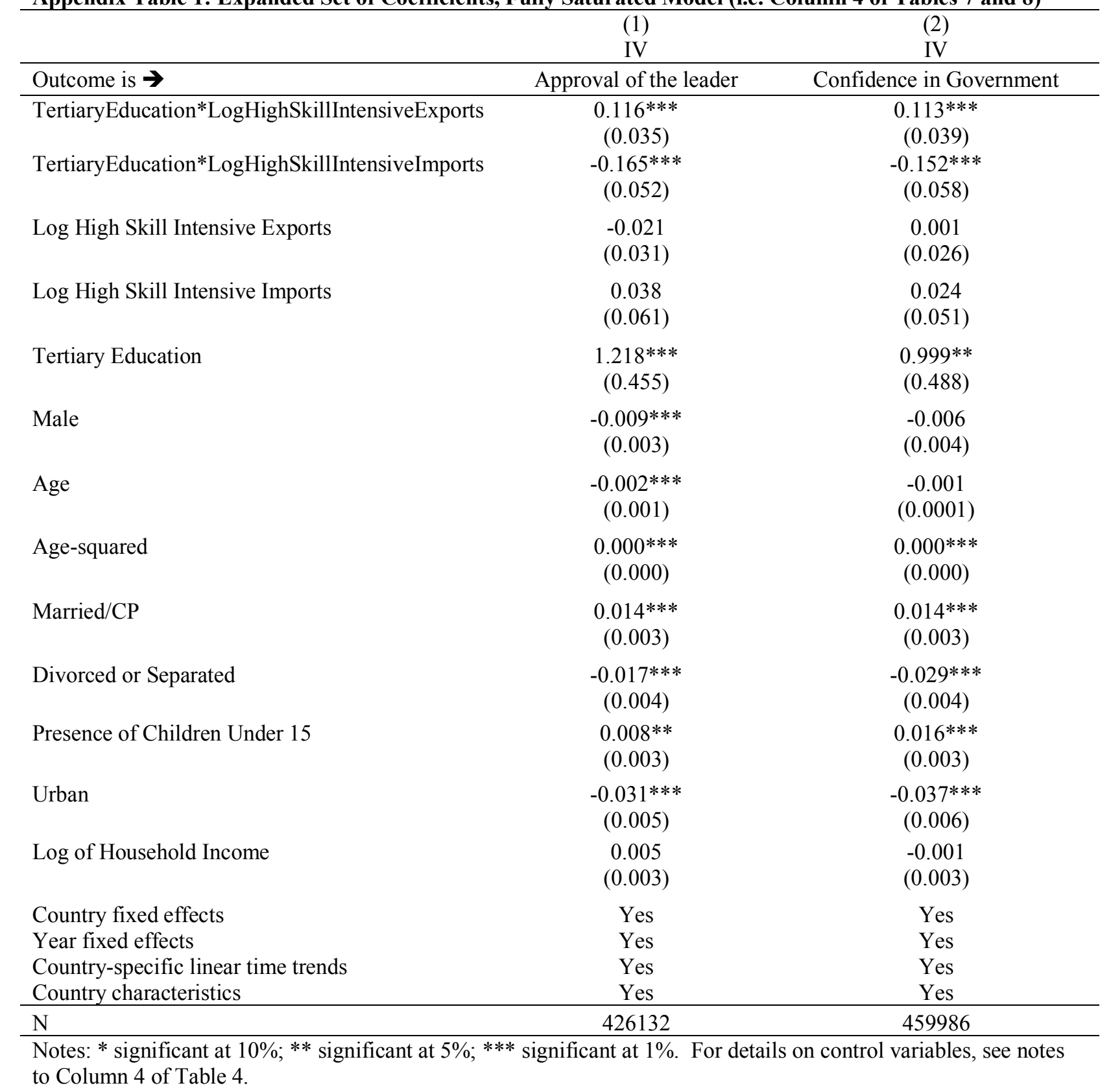


Appendix Table 2: OLS Estimates with Aggregate and High-skill Exports and Imports without Interactions

(1)

OLS
Outcome: Approval of the leader

Log Total Exports

Log Total Imports

R-squared

$\mathrm{N}$

Outcome: Confidence in Government

Log Total Exports

Log Total Imports

R-squared

$\mathrm{N}$

Notes: * significant at $10 \%$; ** significant at $5 \% ; * * *$ significant at $1 \%$. All specifications include multiple language

0.144

0.049

$(0.035)$

$0.133 \quad$ R-squared

426,132

0.057

$(0.075)$

0.017
$(0.040)$

Log High Skill Intensive Exports

0.126

$(0.087)$

Log High Skill Intensive Imports

$\mathrm{N}$

Outcome: Confidence in Government

(2)

OLS

Outcome: Approval of the leader

Log High Skill Intensive Exports

0.010

$(0.026)$

0.009

$(0.051)$

0.142 459,986 and interview type dummies and control for the log of household income throughout, though we do not report them above. Demographic characteristics include: a male dummy, age and its square, dummy variables for marital status (married/civil partnership and divorced/separated), educational attainment (tertiary and secondary), a dummy variable for living in an urban area and presence of children in the household (any child under 15). Country characteristics include: Polity 2, press freedom index, the log of country population, and the log of GDP per capita. Results use the Gallup sampling weights and robust standard errors are clustered at the country level. 
Appendix Table 3: IV Estimates with Share of High-skill Intensive Exports (Imports) as a Percentage of Total Exports (Imports)

\begin{tabular}{|c|c|c|c|c|}
\hline & $\begin{array}{l}\text { (1) } \\
\text { IV }\end{array}$ & $\begin{array}{l}\text { (2) } \\
\text { IV }\end{array}$ & $\begin{array}{l}\text { (3) } \\
\text { IV }\end{array}$ & $\begin{array}{l}\text { (4) } \\
\text { IV }\end{array}$ \\
\hline \multicolumn{5}{|l|}{ Outcome: Approval of the leader } \\
\hline TertiaryEducation*ShareofHighSkillIntensiveExports & $\begin{array}{c}0.280 * * * \\
(0.045)\end{array}$ & $\begin{array}{c}0.268 * * * \\
(0.044)\end{array}$ & $\begin{array}{c}0.273 * * * \\
(0.044)\end{array}$ & $\begin{array}{c}0.274 * * * \\
(0.044)\end{array}$ \\
\hline Share of high skill intensive exports & $\begin{array}{c}0.007 \\
(0.245)\end{array}$ & $\begin{array}{c}0.007 \\
(0.245)\end{array}$ & $\begin{array}{c}0.011 \\
(0.245)\end{array}$ & $\begin{array}{c}0.043 \\
(0.247)\end{array}$ \\
\hline TertiaryEducation*ShareofHighSkillIntensiveImports & $\begin{array}{c}-0.657 * * * \\
(0.128)\end{array}$ & $\begin{array}{c}-0.636^{* * *} \\
(0.126)\end{array}$ & $\begin{array}{c}-0.656^{* * *} \\
(0.128)\end{array}$ & $\begin{array}{c}-0.656^{* * * *} \\
(0.128)\end{array}$ \\
\hline Share of high skill intensive imports & $\begin{array}{c}0.095 \\
(0.143)\end{array}$ & $\begin{array}{c}0.098 \\
(0.143)\end{array}$ & $\begin{array}{c}0.097 \\
(0.143)\end{array}$ & $\begin{array}{c}0.039 \\
(0.144)\end{array}$ \\
\hline Tertiary Education & $\begin{array}{c}0.139 * * * \\
(0.034)\end{array}$ & $\begin{array}{c}0.145^{* * *} \\
(0.033)\end{array}$ & $\begin{array}{c}0.146^{* * *} \\
(0.034)\end{array}$ & $\begin{array}{c}0.146 * * * \\
(0.034)\end{array}$ \\
\hline KP First Stage F-Stat & 28.62 & 28.10 & 28.26 & 28.28 \\
\hline $\mathrm{N}$ & 426132 & 426132 & 426132 & 426132 \\
\hline Country fixed effects & Yes & Yes & Yes & Yes \\
\hline Year fixed effects & Yes & Yes & Yes & Yes \\
\hline Country-specific linear time trends & Yes & Yes & Yes & Yes \\
\hline Demographic characteristics & No & Yes & Yes & Yes \\
\hline Household income & No & No & Yes & Yes \\
\hline Country-level characteristics & No & No & No & Yes \\
\hline
\end{tabular}

Notes: ${ }^{*}$ significant at $10 \% ; * *$ significant at 5\%; ${ }^{* *}$ significant at $1 \%$. For details on control variables, see notes to Table 4 . 
Appendix Table 4: IV Estimates with Share of High-skill Intensive Exports (Imports) as a Percentage of Total Exports (Imports)

\begin{tabular}{|c|c|c|c|c|}
\hline & $\begin{array}{l}(1) \\
\text { IV }\end{array}$ & $\begin{array}{l}\text { (2) } \\
\text { IV }\end{array}$ & $\begin{array}{l}\text { (3) } \\
\text { IV }\end{array}$ & $\begin{array}{l}\text { (4) } \\
\text { IV }\end{array}$ \\
\hline \multicolumn{5}{|l|}{ Outcome: Confidence in Government } \\
\hline TertiaryEducation*ShareofHighSkillIntensiveExports & $\begin{array}{c}0.370^{* * *} \\
(0.047)\end{array}$ & $\begin{array}{c}0.353^{* * *} \\
(0.046)\end{array}$ & $\begin{array}{c}0.353 * * * \\
(0.046)\end{array}$ & $\begin{array}{c}0.354 * * * \\
(0.046)\end{array}$ \\
\hline Share of high skill intensive exports & $\begin{array}{c}0.079 \\
(0.166)\end{array}$ & $\begin{array}{c}0.076 \\
(0.166)\end{array}$ & $\begin{array}{c}0.076 \\
(0.166)\end{array}$ & $\begin{array}{c}0.096 \\
(0.168)\end{array}$ \\
\hline TertiaryEducation*ShareofHighSkillIntensiveImports & $\begin{array}{c}-0.565^{* * *} \\
(0.119)\end{array}$ & $\begin{array}{c}-0.542 * * * \\
(0.117)\end{array}$ & $\begin{array}{c}-0.542 * * * \\
(0.117)\end{array}$ & $\begin{array}{c}-0.543 * * * \\
(0.117)\end{array}$ \\
\hline Share of high skill intensive imports & $\begin{array}{l}0.0738 \\
(0.110)\end{array}$ & $\begin{array}{c}0.078 \\
(0.110)\end{array}$ & $\begin{array}{c}0.078 \\
(0.110)\end{array}$ & $\begin{array}{c}0.045 \\
(0.110)\end{array}$ \\
\hline Tertiary Education & $\begin{array}{c}0.095 * * * \\
(0.032)\end{array}$ & $\begin{array}{c}0.106^{* * *} \\
(0.032)\end{array}$ & $\begin{array}{c}0.106^{* * *} \\
(0.032)\end{array}$ & $\begin{array}{c}0.106 * * * \\
(0.032)\end{array}$ \\
\hline KP First Stage F-Stat & 26.92 & 26.78 & 26.66 & 26.79 \\
\hline $\mathrm{N}$ & 459986 & 459986 & 459986 & 459986 \\
\hline Country fixed effects & Yes & Yes & Yes & Yes \\
\hline Year fixed effects & Yes & Yes & Yes & Yes \\
\hline Country-specific linear time trends & Yes & Yes & Yes & Yes \\
\hline Demographic characteristics & No & Yes & Yes & Yes \\
\hline Household income & No & No & Yes & Yes \\
\hline Country-level characteristics & No & No & No & Yes \\
\hline
\end{tabular}

Notes: * significant at $10 \%$;* significant at $5 \%$; *** significant at $1 \%$. For details on control variables, see notes to Table 4 . 
Appendix Table 5: IV Estimates with Alternative Skilled Definition (Secondary education or above)

Outcome: Approval of the leader

Secondary educ. or above*LogHighSkillIntensiveExports

Log High Skill Intensive Exports

Secondary educ. or above*LogHighSkillIntensiveImports

Log High Skill Intensive Imports

Secondary educ. or above

$\mathrm{N}$

Outcome: Confidence in Government

Secondary educ. or above*LogHighSkillIntensiveExports

Log High Skill Intensive Exports

Secondary educ. or above*LogHighSkillIntensiveImports

Log High Skill Intensive Imports

Secondary educ. or above

$\mathrm{N}$ Notes: * significant at $10 \% ; * *$ sign
see notes to Column 4 of Table 4.
(1)

OLS

(2)

IV

$\begin{array}{cc}0.026^{* * *} & 0.113^{* * *} \\ (0.006) & (0.033) \\ -0.018 & -0.054 \\ (0.025) & (0.028) \\ -0.033^{* * *} & -0.172^{* * *} \\ (0.009) & (0.051) \\ & \\ 0.018 & 0.078 \\ (0.050) & (0.051) \\ 0.147 * & 1.432 * * * \\ (0.079) & (0.454) \\ & \\ 426132 & 426132\end{array}$

\begin{tabular}{cc}
$0.017^{* * *}$ & $0.136^{* * *}$ \\
$(0.005)$ & $(0.039)$ \\
0.007 & -0.045 \\
$(0.021)$ & $(0.026)$ \\
$-0.020^{* * *}$ & $-0.207 * * *$ \\
$(0.008)$ & $(0.061)$ \\
0.004 & $0.088^{* *}$ \\
$(0.038)$ & $(0.042)$ \\
0.029 & $1.724 * * *$ \\
$(0.069)$ & $(0.553)$ \\
459986 & 459986 \\
\hline t $1 \%$. For details on control variables,
\end{tabular}


Appendix Table 6: OLS Estimates with Low-skill Intensive Exports (Imports) and Secondary Education or Less Interactions

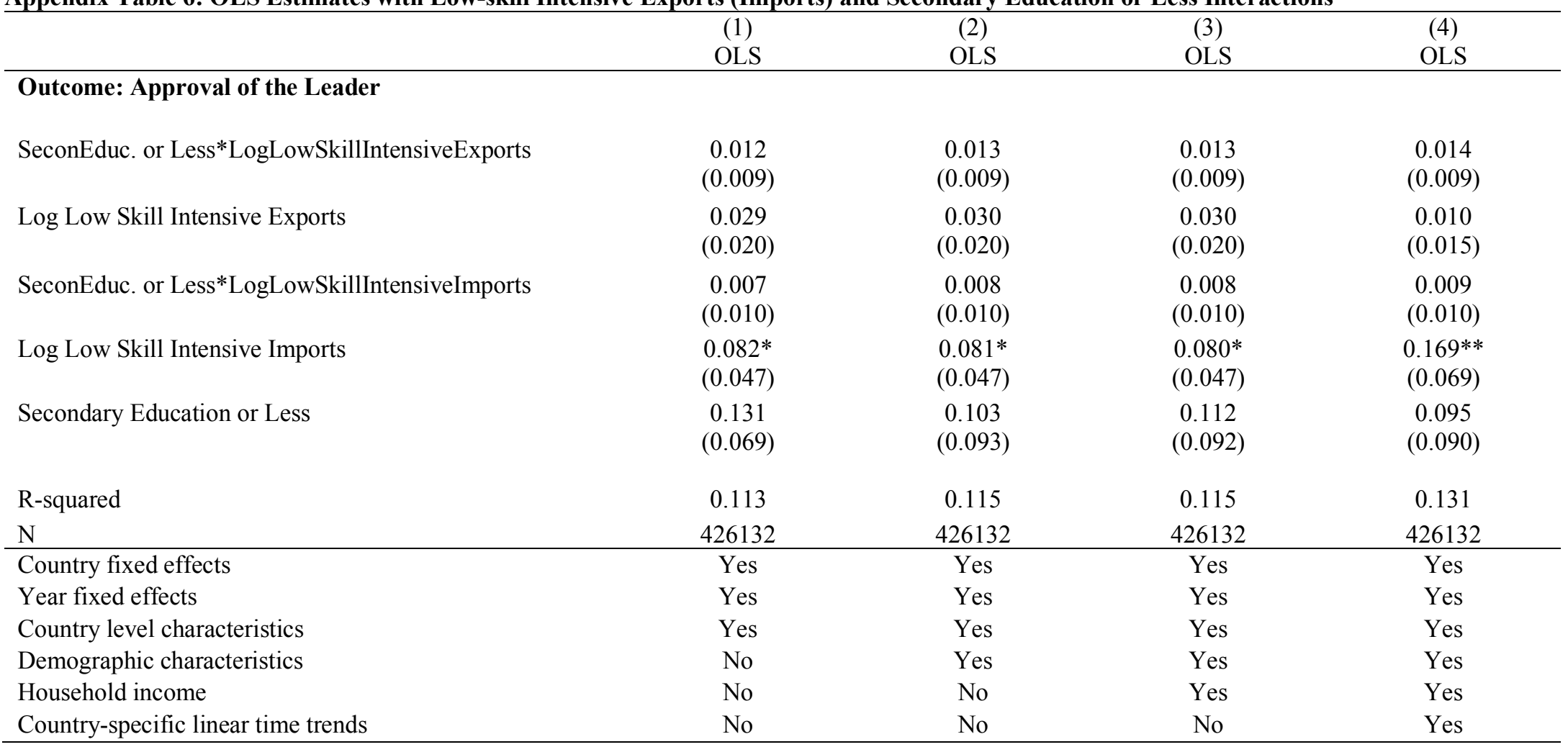

Notes: * significant at 10\%; ** significant at 5\%;*** significant at $1 \%$. For details on control variables, see notes to Table 4 . Low skill intensive exports (imports) is defined as sum of agricultural exports (imports), labour intensive exports (imports), low skill intensive exports (imports) and medium skill intensive exports (imports). 
Appendix Table 7: OLS Estimates with Low-skill Intensive Exports (Imports) and Secondary Education or Less Interactions

(1)

(2)

(3)

(4)

OLS

OLS

OLS

OLS

Outcome: Confidence in Government

SeconEduc. or Less*LogLowSkillIntensiveExports

$\begin{array}{cccc}-0.000 & -0.002 & -0.002 & -0.002 \\ (0.006) & (0.006) & (0.006) & (0.006) \\ 0.030^{*} & 0.031^{* * *} & 0.031^{* * *} & 0.022^{*} \\ (0.011) & (0.011) & (0.011) & (0.012) \\ -0.016^{* *} & -0.014^{*} & -0.014^{*} & -0.012 \\ (0.008) & (0.008) & (0.008) & (0.007) \\ 0.047 & 0.044 & 0.044 & 0.116^{* * *} \\ (0.029) & (0.029) & (0.029) & (0.036) \\ 0.410 * * * & 0.367 * * * & 0.365^{* * *} & 0.349 * * * \\ (0.074) & (0.073) & (0.073) & (0.069)\end{array}$

Log Low Skill Intensive Exports

SeconEduc. or Less*LogLowSkillIntensiveImports

Log Low Skill Intensive Imports

0.131

0.131

0.142

\begin{tabular}{l} 
R-squar \\
$\mathrm{N}$ \\
\hline
\end{tabular}

0.127

459986

459986

459986

Country fixed effects

Yes

Yes

Yes

Yes

Year fixed effects

Country level characteristics

Demographic characteristics

Household income

Yes

Yes

Yes

Yes

No

No

Country-specific linear time trends

No

No

Notes: * significant at 10\%; ** significant at 5\%;*** significant at 1\%. For details on control variables, see notes to Table 4. Low skill intensive exports (imports) is defined as sum of agricultural exports (imports), labour intensive exports (imports), low skill intensive exports (imports) and medium skill intensive exports (imports). 
Appendix Table 8: OLS Estimates with Low-skill Intensive Exports (Imports) and Primary Education or Less Interactions

\begin{tabular}{|c|c|c|c|c|}
\hline & $\begin{array}{l}(1) \\
\text { OLS }\end{array}$ & $\begin{array}{c}(2) \\
\text { OLS }\end{array}$ & $\begin{array}{c}\text { (3) } \\
\text { OLS }\end{array}$ & $\begin{array}{l}(4) \\
\text { OLS }\end{array}$ \\
\hline Outcome $\rightarrow$ & $\begin{array}{l}\text { Approval of the } \\
\text { Leader }\end{array}$ & $\begin{array}{c}\text { Approval of the } \\
\text { Leader }\end{array}$ & $\begin{array}{c}\text { Confidence in } \\
\text { Government }\end{array}$ & $\begin{array}{c}\text { Confidence in } \\
\text { Government }\end{array}$ \\
\hline PrimaryEduc. or Less*LogLowSkillIntensiveExports & $\begin{array}{l}-0.000 \\
(0.010)\end{array}$ & $\begin{array}{l}-0.000 \\
(0.010)\end{array}$ & $\begin{array}{l}-0.004 \\
(0.009)\end{array}$ & $\begin{array}{l}-0.004 \\
(0.009)\end{array}$ \\
\hline Log Low Skill Intensive Exports & $\begin{array}{c}0.015 \\
(0.028)\end{array}$ & $\begin{array}{c}0.015 \\
(0.028)\end{array}$ & $\begin{array}{l}0.049 * \\
(0.026)\end{array}$ & $\begin{array}{l}0.049 * \\
(0.026)\end{array}$ \\
\hline PrimaryEduc. or Less*LogLowSkillIntensiveImports & $\begin{array}{l}-0.004 \\
(0.012)\end{array}$ & $\begin{array}{l}-0.003 \\
(0.012)\end{array}$ & $\begin{array}{l}-0.002 \\
(0.011)\end{array}$ & $\begin{array}{l}-0.001 \\
(0.010)\end{array}$ \\
\hline Log Low Skill Intensive Imports & $\begin{array}{l}0.181 * * \\
(0.070)\end{array}$ & $\begin{array}{l}0.180 * * \\
(0.070)\end{array}$ & $\begin{array}{l}0.102 * \\
(0.057)\end{array}$ & $\begin{array}{l}0.101 * \\
(0.057)\end{array}$ \\
\hline Primary Education & $\begin{array}{c}0.138 \\
(0.115)\end{array}$ & $\begin{array}{c}0.134 \\
(0.116)\end{array}$ & $\begin{array}{l}0.171 * \\
(0.103)\end{array}$ & $\begin{array}{c}0.168 \\
(0.103)\end{array}$ \\
\hline R-squared & 0.134 & 0.134 & 0.144 & 0.144 \\
\hline $\mathrm{N}$ & 406655 & 406655 & 436916 & 436916 \\
\hline Country fixed effects & Yes & Yes & Yes & Yes \\
\hline Year fixed effects & Yes & Yes & Yes & Yes \\
\hline Country level characteristics & Yes & Yes & Yes & Yes \\
\hline Demographic characteristics & Yes & Yes & Yes & Yes \\
\hline Household income & Yes & Yes & Yes & Yes \\
\hline Country-specific linear time trends & Yes & Yes & Yes & Yes \\
\hline Country by skill type fixed effects & No & Yes & No & Yes \\
\hline
\end{tabular}

Notes: * significant at $10 \% ; * *$ significant at $5 \% ; * * *$ significant at $1 \%$. For details on control variables, see notes to Table 4 . Low skill intensive exports (imports) is defined as sum of agricultural exports (imports), labour intensive exports (imports), low skill intensive exports (imports) and medium skill intensive exports (imports). 
Appendix Table 9: OLS Estimates with Low-skill Intensive Exports (Imports) and Secondary Education Interactions

\begin{tabular}{|c|c|c|c|c|}
\hline & $\begin{array}{c}(1) \\
\text { OLS }\end{array}$ & $\begin{array}{l}(2) \\
\text { OLS }\end{array}$ & $\begin{array}{l}(3) \\
\text { OLS }\end{array}$ & $\begin{array}{l}(4) \\
\text { OLS }\end{array}$ \\
\hline Outcome $\rightarrow$ & $\begin{array}{l}\text { Approval of the } \\
\text { Leader }\end{array}$ & $\begin{array}{l}\text { Approval of the } \\
\text { Leader }\end{array}$ & $\begin{array}{c}\text { Confidence in } \\
\text { Government }\end{array}$ & $\begin{array}{c}\text { Confidence in } \\
\text { Government }\end{array}$ \\
\hline SeconEduc. *LogLowSkillIntensiveExports & $\begin{array}{l}-0.008 \\
(0.006)\end{array}$ & $\begin{array}{l}-0.008 \\
(0.006)\end{array}$ & $\begin{array}{l}-0.011 * \\
(0.006)\end{array}$ & $\begin{array}{l}-0.009 \\
(0.006)\end{array}$ \\
\hline Log Low Skill Intensive Exports & $\begin{array}{c}0.018 \\
(0.028)\end{array}$ & $\begin{array}{c}0.018 \\
(0.028)\end{array}$ & $\begin{array}{c}0.052 * * \\
(0.026)\end{array}$ & $\begin{array}{l}0.052 * * \\
(0.026)\end{array}$ \\
\hline SeconEduc. ${ }^{*}$ LogLowSkillIntensiveImports & $\begin{array}{c}0.009 \\
(0.007)\end{array}$ & $\begin{array}{c}0.007 \\
(0.007)\end{array}$ & $\begin{array}{c}0.009 \\
(0.007)\end{array}$ & $\begin{array}{c}0.005 \\
(0.007)\end{array}$ \\
\hline Log Low Skill Intensive Imports & $\begin{array}{c}0.174 * * \\
(0.069)\end{array}$ & $\begin{array}{l}0.175^{* *} \\
(0.069)\end{array}$ & $\begin{array}{c}0.097 \\
(0.058)\end{array}$ & $\begin{array}{l}0.098 * \\
(0.058)\end{array}$ \\
\hline Secondary Education & $\begin{array}{l}-0.064 \\
(0.066)\end{array}$ & $\begin{array}{l}-0.037 \\
(0.071)\end{array}$ & $\begin{array}{l}-0.005 \\
(0.065)\end{array}$ & $\begin{array}{c}0.041 \\
(0.065)\end{array}$ \\
\hline R-squared & 0.134 & 0.134 & 0.144 & 0.144 \\
\hline $\mathrm{N}$ & 406655 & 406655 & 436916 & 436916 \\
\hline Country fixed effects & Yes & Yes & Yes & Yes \\
\hline Year fixed effects & Yes & Yes & Yes & Yes \\
\hline Country level characteristics & Yes & Yes & Yes & Yes \\
\hline Demographic characteristics & Yes & Yes & Yes & Yes \\
\hline Household income & Yes & Yes & Yes & Yes \\
\hline Country-specific linear time trends & Yes & Yes & Yes & Yes \\
\hline Country by skill type fixed effects & No & Yes & No & Yes \\
\hline
\end{tabular}

Notes: * significant at 10\%; ** significant at 5\%;*** significant at 1\%. For details on control variables, see notes to Table 4 . Low skill intensive exports (imports) is defined as sum of agricultural exports (imports), labour intensive exports (imports), low skill intensive exports (imports) and medium skill intensive exports (imports). 
Appendix Table 10: Robustness to Excluding Sub-Periods, Approval of the Leader.

\begin{tabular}{|c|c|c|c|c|}
\hline & $\begin{array}{l}\text { (1) } \\
\text { IV }\end{array}$ & $\begin{array}{l}(2) \\
\text { IV }\end{array}$ & $\begin{array}{l}(3) \\
\text { IV }\end{array}$ & $\begin{array}{l}\text { (4) } \\
\text { IV }\end{array}$ \\
\hline Outcome $\rightarrow$ Approval of the Leader & Excl. 2005-2008 & Excl. 2008-2010 & Excl. 2009-2011 & Excl. 2012-2015 \\
\hline TertiaryEducation*LogHighSkillIntensiveExports & $\begin{array}{c}0.120 * * * \\
(0.038)\end{array}$ & $\begin{array}{c}0.114 * * * \\
(0.033)\end{array}$ & $\begin{array}{c}0.112 * * * \\
(0.033)\end{array}$ & $\begin{array}{c}0.129 * * * \\
(0.048)\end{array}$ \\
\hline Log High Skill Intensive Exports & $\begin{array}{l}-0.007 \\
(0.032)\end{array}$ & $\begin{array}{l}-0.021 \\
(0.034)\end{array}$ & $\begin{array}{l}-0.038 \\
(0.046)\end{array}$ & $\begin{array}{c}0.049 \\
(0.051)\end{array}$ \\
\hline TertiaryEducation*LogHighSkillIntensiveImports & $\begin{array}{c}-0.169^{* * *} \\
(0.057)\end{array}$ & $\begin{array}{c}-0.157 * * * \\
(0.048)\end{array}$ & $\begin{array}{c}-0.157 * * * \\
(0.049)\end{array}$ & $\begin{array}{c}-0.181 * * \\
(0.071)\end{array}$ \\
\hline Log High Skill Intensive Imports & $\begin{array}{c}-0.117 * * \\
(0.057)\end{array}$ & $\begin{array}{c}0.017 \\
(0.061)\end{array}$ & $\begin{array}{c}0.036 \\
(0.088)\end{array}$ & $\begin{array}{c}0.000 \\
(0.131)\end{array}$ \\
\hline Tertiary Education & $\begin{array}{l}1.258 * * \\
(0.501)\end{array}$ & $\begin{array}{c}1.076^{* * * *} \\
(0.408)\end{array}$ & $\begin{array}{c}1.143 * * * \\
(0.422)\end{array}$ & $\begin{array}{l}1.312 * * \\
(0.605)\end{array}$ \\
\hline KP First Stage F-Stat & 22.14 & 21.56 & 22.48 & 21.76 \\
\hline $\mathrm{N}$ & 348306 & 295805 & 276675 & 227283 \\
\hline Country fixed effects & Yes & Yes & Yes & Yes \\
\hline Year fixed effects & Yes & Yes & Yes & Yes \\
\hline Country level characteristics & Yes & Yes & Yes & Yes \\
\hline Demographic characteristics & Yes & Yes & Yes & Yes \\
\hline Household income & Yes & Yes & Yes & Yes \\
\hline Country-specific linear time trends & Yes & Yes & Yes & Yes \\
\hline
\end{tabular}

Notes: $*$ significant at $10 \%$; $*$ significant at 5\%; *** significant at $1 \%$. For details on control variables, see notes to Table 4. 
Appendix Table 11: Robustness to Excluding Sub-Periods, Confidence in Government.

\begin{tabular}{|c|c|c|c|c|}
\hline & $\begin{array}{l}\text { (1) } \\
\text { IV }\end{array}$ & $\begin{array}{l}(2) \\
\text { IV }\end{array}$ & $\begin{array}{l}(3) \\
\text { IV }\end{array}$ & $\begin{array}{l}\text { (4) } \\
\text { IV }\end{array}$ \\
\hline Outcome $\rightarrow$ Confidence in Government & Excl. 2005-2008 & Excl. 2008-2010 & Excl. 2009-2011 & Excl. 2012-2015 \\
\hline TertiaryEducation*LogHighSkillIntensiveExports & $\begin{array}{c}0.134 * * * \\
(0.044)\end{array}$ & $\begin{array}{c}0.118 * * * \\
(0.039)\end{array}$ & $\begin{array}{c}0.103 * * * \\
(0.038)\end{array}$ & $\begin{array}{c}0.093 * * \\
(0.048)\end{array}$ \\
\hline Log High Skill Intensive Exports & $\begin{array}{l}-0.001 \\
(0.028)\end{array}$ & $\begin{array}{c}0.012 \\
(0.031)\end{array}$ & $\begin{array}{l}-0.026 \\
(0.033)\end{array}$ & $\begin{array}{c}0.058 \\
(0.039)\end{array}$ \\
\hline TertiaryEducation*LogHighSkillIntensiveImports & $\begin{array}{c}-0.181 * * * \\
(0.066)\end{array}$ & $\begin{array}{c}-0.154 * * * \\
(0.055)\end{array}$ & $\begin{array}{c}-0.135^{* *} \\
(0.054)\end{array}$ & $\begin{array}{l}-0.126^{*} \\
(0.073)\end{array}$ \\
\hline Log High Skill Intensive Imports & $\begin{array}{l}-0.066 \\
(0.048)\end{array}$ & $\begin{array}{c}0.001 \\
(0.063)\end{array}$ & $\begin{array}{l}-0.017 \\
(0.073)\end{array}$ & $\begin{array}{l}-0.029 \\
(0.068)\end{array}$ \\
\hline Tertiary Education & $\begin{array}{l}1.227 * * \\
(0.570)\end{array}$ & $\begin{array}{c}0.943 * * \\
(0.447)\end{array}$ & $\begin{array}{l}0.820 * \\
(0.437)\end{array}$ & $\begin{array}{c}0.839 \\
(0.649)\end{array}$ \\
\hline KP First Stage F-Stat & 23.84 & 22.54 & 23.32 & 24.21 \\
\hline $\mathrm{N}$ & 371620 & 329454 & 308931 & 239421 \\
\hline Country fixed effects & Yes & Yes & Yes & Yes \\
\hline Year fixed effects & Yes & Yes & Yes & Yes \\
\hline Country level characteristics & Yes & Yes & Yes & Yes \\
\hline Demographic characteristics & Yes & Yes & Yes & Yes \\
\hline Household income & Yes & Yes & Yes & Yes \\
\hline Country-specific linear time trends & Yes & Yes & Yes & Yes \\
\hline
\end{tabular}

Notes: * significant at 10\%; ** significant at 5\%;*** significant at $1 \%$. For details on control variables, see notes to Table 4. 
Appendix Table 12: Robustness to Including Interactions of Skill Levels with GDP Per Capita

\begin{tabular}{|c|c|c|c|c|}
\hline & $\begin{array}{c}(1) \\
\text { OLS }\end{array}$ & $\begin{array}{c}(2) \\
\text { OLS }\end{array}$ & $\begin{array}{l}\text { (3) } \\
\text { IV }\end{array}$ & $\begin{array}{l}\text { (4) } \\
\text { IV }\end{array}$ \\
\hline Outcome $\rightarrow$ & $\begin{array}{l}\text { Approval of the } \\
\text { Leader }\end{array}$ & $\begin{array}{c}\text { Confidence in } \\
\text { Government }\end{array}$ & $\begin{array}{l}\text { Approval of the } \\
\text { Leader }\end{array}$ & $\begin{array}{c}\text { Confidence in } \\
\text { Government }\end{array}$ \\
\hline TertiaryEducation*LogHighSkillIntensiveExports & $\begin{array}{c}0.035 * * * \\
(0.007)\end{array}$ & $\begin{array}{c}0.016^{* *} \\
(0.007)\end{array}$ & $\begin{array}{c}0.065^{* *} \\
(0.027)\end{array}$ & $\begin{array}{c}0.046 \\
(0.028)\end{array}$ \\
\hline Log High Skill Intensive Exports & $\begin{array}{l}-0.015 \\
(0.027)\end{array}$ & $\begin{array}{c}0.015 \\
(0.023)\end{array}$ & $\begin{array}{l}-0.017 \\
(0.034)\end{array}$ & $\begin{array}{c}0.013 \\
(0.029)\end{array}$ \\
\hline TertiaryEducation*LogHighSkillIntensiveImports & $\begin{array}{c}-0.051 * * * \\
(0.009)\end{array}$ & $\begin{array}{c}-0.028 * * * \\
(0.008)\end{array}$ & $\begin{array}{c}-0.117 * * * \\
(0.039)\end{array}$ & $\begin{array}{c}-0.088^{* *} \\
(0.040)\end{array}$ \\
\hline Log High Skill Intensive Imports & $\begin{array}{l}-0.004 \\
(0.052)\end{array}$ & $\begin{array}{l}-0.011 \\
(0.042)\end{array}$ & $\begin{array}{c}0.003 \\
(0.067)\end{array}$ & $\begin{array}{l}-0.005 \\
(0.058)\end{array}$ \\
\hline Tertiary Education & $\begin{array}{l}0.126^{*} \\
(0.072)\end{array}$ & $\begin{array}{c}-0.156^{* *} \\
(0.070)\end{array}$ & $\begin{array}{c}0.745 * * \\
(0.337)\end{array}$ & $\begin{array}{c}0.395 \\
(0.334)\end{array}$ \\
\hline Log GDP Per Capita*Tertiary Education & $\begin{array}{c}0.909 * * * \\
(0.202)\end{array}$ & $\begin{array}{c}0.694 * * * \\
(0.171)\end{array}$ & $\begin{array}{c}0.934 * * * \\
(0.291)\end{array}$ & $\begin{array}{c}0.714 * * * \\
(0.250)\end{array}$ \\
\hline Log GDP Per Capita*Secondary Education or Less & $\begin{array}{c}0.877 * * * \\
(0.202)\end{array}$ & $\begin{array}{c}0.644 * * * \\
(0.171)\end{array}$ & $\begin{array}{c}0.877 * * * \\
(0.293)\end{array}$ & $\begin{array}{c}0.645 * * * \\
(0.250)\end{array}$ \\
\hline KP First Stage F-Stat & -- & -- & 24.18 & 23.91 \\
\hline $\mathrm{N}$ & 406655 & 436916 & 406655 & 436916 \\
\hline Country fixed effects & Yes & Yes & Yes & Yes \\
\hline Year fixed effects & Yes & Yes & Yes & Yes \\
\hline Country level characteristics & Yes & Yes & Yes & Yes \\
\hline Demographic characteristics & Yes & Yes & Yes & Yes \\
\hline Household income & Yes & Yes & Yes & Yes \\
\hline Country-specific linear time trends & Yes & Yes & Yes & Yes \\
\hline
\end{tabular}

Notes: $*$ significant at 10\%; ** significant at 5\%; *** significant at 1\%. For details on control variables, see notes to Table 4. 
Appendix Table 13: Robustness to Including Country-Skill Fixed Effects

\begin{tabular}{|c|c|c|c|c|}
\hline & $\begin{array}{c}(1) \\
\text { OLS }\end{array}$ & $\begin{array}{c}(2) \\
\text { OLS }\end{array}$ & $\begin{array}{l}\text { (3) } \\
\text { IV }\end{array}$ & $\begin{array}{l}\text { (4) } \\
\text { IV }\end{array}$ \\
\hline Outcome $\rightarrow$ & $\begin{array}{l}\text { Approval of the } \\
\text { Leader }\end{array}$ & $\begin{array}{l}\text { Confidence in } \\
\text { Government }\end{array}$ & $\begin{array}{l}\text { Approval of the } \\
\text { Leader }\end{array}$ & $\begin{array}{c}\text { Confidence in } \\
\text { Government }\end{array}$ \\
\hline TertiaryEducation*LogHighSkillIntensiveExports & $\begin{array}{c}0.047 * * * \\
(0.007)\end{array}$ & $\begin{array}{c}0.037 * * * \\
(0.006)\end{array}$ & $\begin{array}{c}0.113 * * * \\
(0.032)\end{array}$ & $\begin{array}{c}0.109 * * * \\
(0.035)\end{array}$ \\
\hline Log High Skill Intensive Exports & $\begin{array}{l}-0.017 \\
(0.027)\end{array}$ & $\begin{array}{c}0.013 \\
(0.023)\end{array}$ & $\begin{array}{l}-0.022 \\
(0.033)\end{array}$ & $\begin{array}{c}0.007 \\
(0.028)\end{array}$ \\
\hline TertiaryEducation*LogHighSkillIntensiveImports & $\begin{array}{c}-0.054 * * * \\
(0.009)\end{array}$ & $\begin{array}{c}-0.032 * * * \\
(0.009)\end{array}$ & $\begin{array}{c}-0.159 * * * \\
(0.047)\end{array}$ & $\begin{array}{c}-0.146^{* * *} \\
(0.052)\end{array}$ \\
\hline Log High Skill Intensive Imports & $\begin{array}{l}-0.005 \\
(0.052)\end{array}$ & $\begin{array}{c}-0.012 \\
(0.042)\end{array}$ & $\begin{array}{c}0.005 \\
(0.066)\end{array}$ & $\begin{array}{l}-0.001 \\
(0.057)\end{array}$ \\
\hline Tertiary Education & $\begin{array}{c}0.192 * * * \\
(0.073)\end{array}$ & $\begin{array}{l}-0.065 \\
(0.072)\end{array}$ & $\begin{array}{c}1.158 * * * \\
(0.406)\end{array}$ & $\begin{array}{l}0.958 * * \\
(0.445)\end{array}$ \\
\hline KP First Stage F-Stat & -- & -- & 26.84 & 25.21 \\
\hline $\mathrm{N}$ & 426132 & 459986 & 426132 & 459986 \\
\hline Country fixed effects & Yes & Yes & Yes & Yes \\
\hline Year fixed effects & Yes & Yes & Yes & Yes \\
\hline Country level characteristics & Yes & Yes & Yes & Yes \\
\hline Demographic characteristics & Yes & Yes & Yes & Yes \\
\hline Household income & Yes & Yes & Yes & Yes \\
\hline Country-specific linear time trends & Yes & Yes & Yes & Yes \\
\hline Country by skill type fixed effects & Yes & Yes & Yes & Yes \\
\hline
\end{tabular}

Notes: * significant at 10\%; ** significant at 5\%; *** significant at 1\%. For details on control variables, see notes to Table 4. 
Appendix Table 14: IV Estimates - Sub-sample Analysis by Returns to Education by Country

(1) IV

(2) IV

(3) IV

Returns to educ.: bottom tercile Returns to educ.: middle tercile

Returns to educ: top tercile

Outcome: Approval of the leader

TertiaryEducation*LogHighSkillIntensiveExports

$\begin{array}{ccc}-0.048 & 0.136^{* * *} & 0.501 \\ (0.083) & (0.043) & (3.308) \\ -0.062 & -0.010 & 0.024 \\ (0.117) & (0.057) & (0.130) \\ 0.066 & -0.177^{* * *} & -0.856 \\ (0.117) & (0.061) & (5.694)\end{array}$

Log High Skill Intensive Exports

$\begin{array}{lll}0.100 & 0.063 & -0.043\end{array}$

Log High Skill Intensive Imports

$(0.145)$

(0.111)

(0.405)

Tertiary Education

$-0.428$

$1.042 * *$

$-8.751$

(0.875)

$(0.467)$

(8.493)

N

TertiaryEducation*LogHighSkillIntensiveExports

128115

154310

143707

Log High Skill Intensive Exports

$-0.084$

$0.153 * * *$

0.646

(0.105)

(0.042)

(4.368)

$-0.021$

0.021

0.029

(0.088)

(0.042)

(0.171)

TertiaryEducation*LogHighSkillIntensiveImports

0.139

$-0.196 * * *$

$-1.084$

(0.146)

(0.060)

(7.492)

Log High Skill Intensive Imports

$-0.123$

0.069

$-0.041$

(0.088)

(0.088)

(0.526)

Tertiary Education

$-1.324$

(1.080)

$1.117 * *$

(0.475)

$-10.840$

145965

$\frac{165630}{14839}$

(6.603)

$\mathrm{N}$

Notes: $*$ significant at $10 \% ; * *$ significant at $5 \% ; * *$ significant at $1 \%$. In bottom tercile wage premia ranges from .08 to .39 with a mean of
tercile wage premia ranges from .39 to .78 with a mean of .57 , and in top tercile wage premia ranges from .78 to 2.44 with a mean of 1.03 . 
Appendix Table 15: IV Estimates - Controlling for Oil Revenue

\section{(1)}

IV

(2)

IV

Outcome is $\rightarrow$ Approval of the leader

Confidence in government

TertiaryEducation*LogHighSkillIntensiveExports

$0.117 * * *$

$(0.032)$

$0.111^{* * *}$

Log High Skill Intensive Exports

$-0.003$

$(0.037)$

$(0.030)$

0.012

$-0.163 * * *$

$(0.026)$

TertiaryEducation*LogHighSkillIntensiveImports

$(0.047)$

$-0.147 * * *$

0.028

(0.053)

Log High Skill Intensive Imports

$(0.067)$

0.035

$1.152 * * *$

$(0.047)$

Tertiary Education

$(0.398)$

$0.916^{* *}$

$(0.449)$

Log Oil Revenue

0.000

0.000

$(0.000)$

$(0.000)$

TertiaryEducation* LogOilRevenue

0.000

$-0.000$

$(0.000)$

$(0.000)$

$\mathrm{N}$

395127

428177

Notes: * significant at $10 \%$; ** significant at $5 \%$; *** significant at $1 \%$. For details on control variables, see notes to Column 4 of Table 4. 
Appendix Table 16: IV Estimates - Countries with Positive and Negative Net High-skill Exports and Imports

(1)

IV

Net exporters

Outcome: Approval of the leader

TertiaryEducation*LogHighSkillIntensiveExports

0.067

$(0.084)$

0.210

$(0.150)$

$-0.096$

$(0.069)$

(2)

IV

Net importers

Log High Skill Intensive Exports

TertiaryEducation*LogHighSkillIntensiveImports

Log High Skill Intensive Imports

$-0.195$

(0.172)

0.723

(1.193)

78723

Outcome: Confidence in Government

TertiaryEducation*LogHighSkillIntensiveExports

0.025

$(0.108)$

$0.136^{* * *}$

$(0.026)$

Log High Skill Intensive Exports

0.098

0.002

$(0.122)$

$(0.021)$

TertiaryEducation*LogHighSkillIntensiveImports

$-0.042$

$(0.082)$

$-0.178^{* * *}$

$-0.190$

$(0.111)$

1.745

$(1.951)$

Log High Skill Intensive Imports

Tertiary Education

\footnotetext{
90258

90258

$\mathrm{N}$

Notes: * significant at $10 \%$; ** significant at $5 \%$; *** significant at $1 \%$. For details on control variables, see notes to Column 4 of Table 4 . Net exporters refer to the countries where high skill intensive exports are greater than high skill intensive imports (using averages over the sample period). Net importers refer to the countries where high skill intensive imports are greater than high skill intensive imports (using averages over the sample period).
} 
Appendix Table 17: IV Estimates - Single Instruments

\begin{tabular}{|c|c|c|}
\hline Outcome is $\rightarrow$ & $\begin{array}{c}\text { (1) } \\
\text { IV } \\
\text { Approval of the leader }\end{array}$ & $\begin{array}{c}\text { (2) } \\
\text { IV } \\
\text { Confidence in Government }\end{array}$ \\
\hline TertiaryEducation*LogHighSkillIntensiveExports & $\begin{array}{c}0.008^{* * *} * \\
(0.002)\end{array}$ & $\begin{array}{c}0.013 * * * \\
(0.002)\end{array}$ \\
\hline Log High Skill Intensive Exports & $\begin{array}{l}-0.009 \\
(0.024)\end{array}$ & $\begin{array}{c}0.007 \\
(0.020)\end{array}$ \\
\hline Tertiary Education & $\begin{array}{c}-0.171 * * * \\
(0.057)\end{array}$ & $\begin{array}{c}-0.298 * * * \\
(0.057)\end{array}$ \\
\hline $\mathrm{N}$ & 399446 & 435072 \\
\hline TertiaryEducation*LogHighSkillIntensiveImports & $\begin{array}{c}-0.028 * * * \\
(0.011)\end{array}$ & $\begin{array}{l}-0.010 \\
(0.010)\end{array}$ \\
\hline Log High Skill Intensive Imports & $\begin{array}{c}0.004 \\
(0.045)\end{array}$ & $\begin{array}{c}0.012 \\
(0.035)\end{array}$ \\
\hline Tertiary Education & $\begin{array}{c}0.674 * * \\
(0.262)\end{array}$ & $\begin{array}{c}0.252 \\
(0.238)\end{array}$ \\
\hline $\mathrm{N}$ & 406602 & 443126 \\
\hline
\end{tabular}




\begin{tabular}{|c|c|}
\hline TDRE1 & High-skill: Electronics (excluding parts and components) \\
\hline 751 & Office machines \\
\hline 752 & Automatic data processing machines, n.e.s. \\
\hline 761 & Television receivers, whether or not combined \\
\hline 762 & Radio-broadcast receivers, whether or not combined \\
\hline 763 & Sound recorders or reproducers \\
\hline TDRE2 & High-skill: Parts and components for electrical and electronic goods \\
\hline 759 & Parts, accessories for machines of groups 751,752 \\
\hline 764 & Telecommunication equipment, n.e.s.; \& parts, n.e.s. \\
\hline 776 & Cathode valves \& tubes \\
\hline TDRE3 & High-skill: Other, excluding electronics \\
\hline 511 & Hydrocarbons, n.e.s., \& halogenated, nitr. derivative \\
\hline 512 & Alcohols, phenols, halogenat., sulfonat., nitrat. der. \\
\hline 513 & Carboxylic acids, anhydrides, halides, per.; derivati. \\
\hline 514 & Nitrogen-function compounds \\
\hline 515 & Organo-inorganic, heterocycl. compounds, nucl. acids \\
\hline 516 & Other organic chemicals \\
\hline 522 & Inorganic chemical elements, oxides \& halogen salts \\
\hline 523 & Metallic salts \& peroxysalts, of inorganic acids \\
\hline 524 & Other inorganic chemicals \\
\hline 525 & Radio-actives and associated materials \\
\hline 531 & Synth. organic colouring matter \& colouring lakes \\
\hline 532 & Dyeing \& tanning extracts, synth. tanning materials \\
\hline 533 & Pigments, paints, varnishes and related materials \\
\hline 541 & Medicinal and pharmaceutical products, excluding 542 \\
\hline 542 & Medicaments (incl. veterinary medicaments) \\
\hline 551 & Essential oils, perfume \& flavour materials \\
\hline 553 & Perfumery, cosmetics or toilet prepar. (excluding soaps) \\
\hline 554 & Soaps, cleansing and polishing preparations \\
\hline 562 & Fertilizers (other than those of group 272) \\
\hline 571 & Polymers of ethylene, in primary forms \\
\hline 572 & Polymers of styrene, in primary forms \\
\hline 573 & Polymers of vinyl chloride or halogenated olefins \\
\hline 574 & Polyethers, epoxide resins; polycarbonat., polyesters \\
\hline
\end{tabular}




\begin{tabular}{|l|l|}
\hline 575 & Other plastics, in primary forms \\
\hline 579 & Waste, parings and scrap, of plastics \\
\hline 581 & Tubes, pipes and hoses of plastics \\
\hline 582 & Plates, sheets, films, foil \& strip, of plastics \\
\hline 583 & Monofilaments, of plastics, cross-section > 1mm \\
\hline 591 & Insectides \& similar products, for retail sale \\
\hline 592 & Starche, wheat gluten; albuminoidal substances; glues \\
\hline 593 & Explosives and pyrotechnic products \\
\hline 597 & Prepared addit. for miner. oils; lubricat., de-icing \\
\hline 598 & Miscellaneous chemical products, n.e.s. \\
\hline 792 & Aircraft \& associated equipment; spacecraft, etc. \\
\hline 871 & Optical instruments \& apparatus, n.e.s. \\
\hline 872 & Instruments \& appliances, n.e.s., for medical, etc. \\
\hline 873 & Meters \& counters, n.e.s. \\
\hline 874 & Measuring, analysing \& controlling apparatus, n.e.s. \\
\hline 881 & Photographic apparatus \& equipment, n.e.s. \\
\hline 882 & Cinematographic \& photographic supplies \\
\hline 883 & Cinematograph films, exposed \& developed \\
\hline 884 & Optical goods, n.e.s. \\
\hline 885 & Watches \& clocks \\
\hline 891 & Arms \& ammunition \\
\hline 892 & Printed matter \\
\hline 896 & Works of art, collectors' pieces \& antiques \\
\hline 897 & Jewellery \& articles of precious materia., n.e.s. \\
\hline 898 & Musical instruments, parts; records, tapes \& similar \\
\hline & \\
\hline
\end{tabular}

Note: The Standard International Trade Classification (SITC) is a statistical classification of the commodities entering external trade, which is provided by UNCTADstat. The current international standard is the SITC, Revision 3. 
Appendix Table 19: Classification of High-Knowledge Intensive Services

\begin{tabular}{|c|c|c|}
\hline ISIC Code & EBOPS Code & Service Industry \\
\hline 642 & 247 & Telecommunications services \\
\hline 65 & 260 & Financial services \\
\hline 66 & $253,254,255,256,257,258$ & $\begin{array}{l}\text { Insurance services } \\
\text { Life insurance and pension funding } \\
\text { Freight insurance } \\
\text { Other direct insurance } \\
\text { Reinsurance } \\
\text { Auxiliary services }\end{array}$ \\
\hline 72 & 263 & Computer services \\
\hline 73 & 279 & Research and development \\
\hline 74 & $275,276,277,278,280,284$ & $\begin{array}{l}\text { Legal services } \\
\text { Business and management consulting and } \\
\text { public relations services } \\
\text { Accounting, auditing, bookkeeping, and tax } \\
\text { consulting services } \\
\text { Advertising, market research, and public } \\
\text { opinion polling } \\
\text { Architectural, engineering, and other } \\
\text { technical services } \\
\text { Other business service }\end{array}$ \\
\hline
\end{tabular}

Notes: EBOPS data from UN COMTRADE do not classify exports and imports of services by skills. Therefore, we use ISIC-EBOPS conversion tables to identify "high-knowledge intensive services" using the definitions provided by the United Nations Manual on Statistics of International Trade in Services (2002). 